San Jose State University

SJSU ScholarWorks

Mineta Transportation Institute Publications

$1-2022$

\title{
Can Californian Households Save Money on Transportation Costs by Living in Transit-Oriented Developments (TODs)?
}

Hongwei Dong

California State University, Fresno

Follow this and additional works at: https://scholarworks.sjsu.edu/mti_publications

Part of the Policy Design, Analysis, and Evaluation Commons, Transportation Commons, and the Urban Studies Commons

\section{Recommended Citation}

Hongwei Dong. "Can Californian Households Save Money on Transportation Costs by Living in TransitOriented Developments (TODs)?" Mineta Transportation Institute Publications (2022). https://doi.org/ $10.31979 / \mathrm{mti} .2022 .2012$

This Report is brought to you for free and open access by SJSU ScholarWorks. It has been accepted for inclusion in Mineta Transportation Institute Publications by an authorized administrator of SJSU ScholarWorks. For more information, please contact scholarworks@sjsu.edu. 


\section{SJSU}

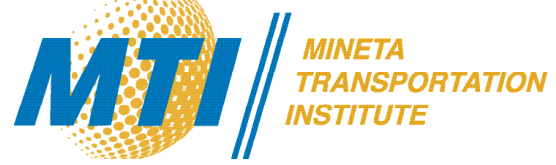

Can Californian Households Save Money on Transportation Costs by Living in Transit-Oriented Developments (TODs)?

Hongwei Dong

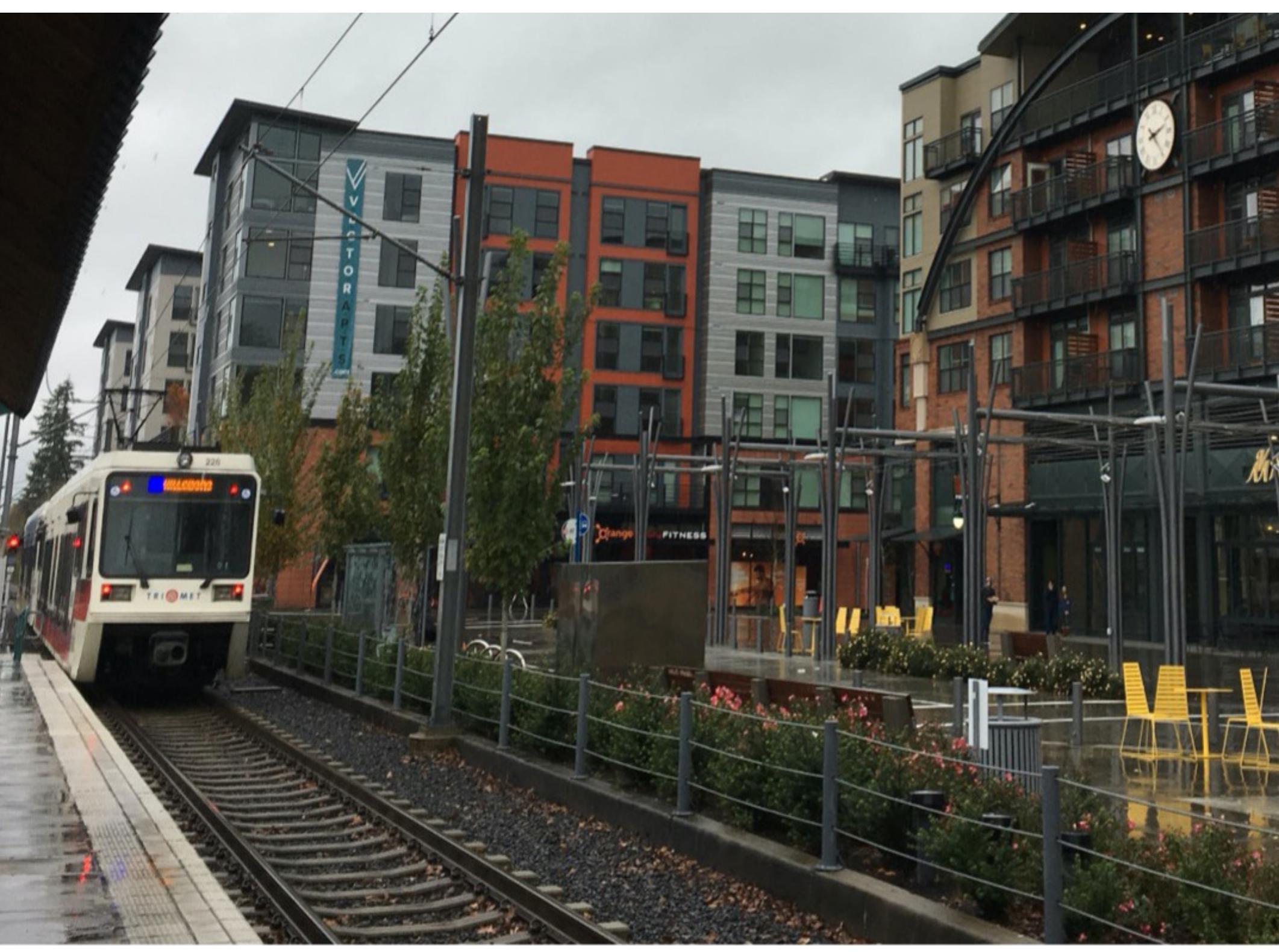

California State University
Transportation Consortium

FRESNGSTATE

Discovery. Diversity. Distinction. 


\section{Mineta Transportation Institute}

Founded in 1991, the Mineta Transportation Institute (MTI), an organized research and training unit in partnership with the Lucas College and Graduate School of Business at San José State University (SJSU), increases mobility for all by improving the safety, efficiency, accessibility, and convenience of our nation's transportation system. Through research, education, workforce development, and technology transfer, we help create a connected world. MTI leads the Mineta Consortium for Transportation Mobility (MCTM) funded by the U.S. Department of Transportation and the California State University Transportation Consortium (CSUTC) funded by the State of California through Senate Bill 1. MTI focuses on three primary responsibilities:

\section{Research}

MTI conducts multi-disciplinary research focused on surface transportation that contributes to effective decision making. Research areas include: active transportation; planning and policy; security and counterterrorism; sustainable transportation and land use; transit and passenger rail; transportation engineering; transportation finance; transportation technology; and workforce and labor. MTI research publications undergo expert peer review to ensure the quality of the research.

\section{Education and Workforce}

To ensure the efficient movement of people and products, we must prepare a new cohort of transportation professionals who are ready to lead a more diverse, inclusive, and equitable transportation industry. To help achieve this, MTI sponsors a suite of workforce development and education opportunities. The Institute supports educational programs offered by the Lucas Graduate School of Business: a
Master of Science in Transportation Management, plus graduate certificates that include High-Speed and Intercity Rail Management and Transportation Security Management. These flexible programs offer live online classes so that working transportation professionals can pursue an advanced degree regardless of their location.

\section{Information and Technology Transfer}

MTI utilizes a diverse array of dissemination methods and media to ensure research results reach those responsible for managing change. These methods include publication, seminars, workshops, websites, social media, webinars, and other technology transfer mechanisms. Additionally, MTI promotes the availability of completed research to professional organizations and works to integrate the research findings into the graduate education program. MTI's extensive collection of transportation-related publications is integrated into San José State University's world-class Martin Luther King, Jr. Library.

\section{Disclaimer}

The contents of this report reflect the views of the authors, who are responsible for the facts and accuracy of the information presented herein. This document is disseminated in the interest of information exchange. MTI's research is funded, partially or entirely, by grants from the California Department of Transportation, the California State University Office of the Chancellor, the U.S. Department of Homeland Security, and the U.S. Department of Transportation, who assume no liability for the contents or use thereof. This report does not constitute a standard specification, design standard, or regulation. 
Report 22-01

\section{Can Californian Households Save Money on Transportation Costs by Living in Transit-Oriented Developments (TODs)?}

Hongwei Dong

January 2022

A publication of the

Mineta Transportation Institute

Created by Congress in 1991

College of Business

San José State University

San José, CA 95192-0219 


\section{TECHNICAL REPORT \\ DOCUMENTATION PAGE}

\begin{tabular}{|c|c|c|c|}
\hline $\begin{array}{l}\text { 1. Report No. } \\
22-01\end{array}$ & 2. Government Accession No. & \multicolumn{2}{|c|}{ 3. Recipient's Catalog No. } \\
\hline \multirow{2}{*}{\multicolumn{2}{|c|}{$\begin{array}{l}\text { 4. Title and Subtitle } \\
\text { Can Californian Households Save Money on Transportation } \\
\text { Costs by Living in Transit-Oriented Developments (TODs)? }\end{array}$}} & \multicolumn{2}{|l|}{$\begin{array}{l}\text { 5. Report Date } \\
\text { January } 2022\end{array}$} \\
\hline & & \multicolumn{2}{|c|}{$\begin{array}{l}\text { 6. Performing Organization } \\
\text { Code }\end{array}$} \\
\hline \multicolumn{2}{|l|}{$\begin{array}{l}\text { 7. Authors } \\
\text { Hongwei Dong, PhD }\end{array}$} & \multicolumn{2}{|c|}{$\begin{array}{l}\text { 8. Performing Organization } \\
\text { Report } \\
\text { CA-MTI-2012 }\end{array}$} \\
\hline \multirow{2}{*}{\multicolumn{2}{|c|}{$\begin{array}{l}\text { 9. Performing Organization Name and Address } \\
\text { Mineta Transportation Institute } \\
\text { College of Business } \\
\text { San José State University } \\
\text { San José, CA 95192-0219 }\end{array}$}} & \multicolumn{2}{|c|}{ 10. Work Unit No. } \\
\hline & & \multicolumn{2}{|c|}{$\begin{array}{l}\text { 11. Contract or Grant No. } \\
\text { ZSB12017-SJAUX }\end{array}$} \\
\hline \multirow{2}{*}{\multicolumn{2}{|c|}{$\begin{array}{l}\text { 12. Sponsoring Agency Name and Address } \\
\text { State of California SB1 2017/2018 } \\
\text { Trustees of the California State University } \\
\text { Sponsored Programs Administration } \\
401 \text { Golden Shore, } 5^{\text {th }} \text { Floor } \\
\text { Long Beach, CA } 90802\end{array}$}} & \multicolumn{2}{|c|}{$\begin{array}{l}\text { 13. Type of Report and Period } \\
\text { Covered }\end{array}$} \\
\hline & & \multicolumn{2}{|c|}{ 14. Sponsoring Agency Code } \\
\hline \multicolumn{4}{|l|}{ 15. Supplemental Notes } \\
\hline \multicolumn{4}{|c|}{$\begin{array}{l}\text { Many residents in large Californian metropolitan areas are heavily burdened by housing costs. Advocates, researchers, } \\
\text { and elected officials in California are debating whether transit-oriented development (TOD) could be an effective } \\
\text { tool to mitigate the housing affordability problem by increasing housing supply and reducing transportation costs in } \\
\text { transit-rich neighborhoods. This study contributes to this debate by estimating how much Californian families can } \\
\text { save on transportation costs by living in transit-oriented developments (TODs). By utilizing the confidential version } \\
\text { of the } 2010-2012 \text { California Household Travel Survey, this study evaluates the impact of TOD on household } \\
\text { transportation expenditures by comparing TOD households with two control groups. When controlling for } \\
\text { household demographics, TOD households save } \$ 1,232 \text { per year on transportation expenditures-18\% of their total } \\
\text { annual transportation expenditures. When controlling for both demographics and neighborhood environment, TOD } \\
\text { households save } \$ 429 \text { per year-about } 6 \% \text { of their total annual transportation expenditures. The study confirms that } \\
\text { Californian households save money on transportation costs by living in TODs mainly because they own fewer } \\
\text { vehicles. About two-thirds of the savings can be attributed to transit-friendly neighborhood environment and one- } \\
\text { third to access to rail transit, which highlights the importance of integrating a rail transit system with supportive land } \\
\text { use planning and neighborhood design. }\end{array}$} \\
\hline $\begin{array}{l}\text { 17. Key Words } \\
\text { TOD, Transportation expenditure, } \\
\text { Propensity score matching }\end{array}$ & \multicolumn{3}{|c|}{$\begin{array}{l}\text { 18. Distribution Statement } \\
\text { No restrictions. This document is available to } \\
\text { the public through The National Technical } \\
\text { Information Service, Springfield, VA } 22161 .\end{array}$} \\
\hline $\begin{array}{l}\text { 19. Security Classif. (of this report) } \\
\text { Unclassified }\end{array}$ & $\begin{array}{l}\text { 20. Security Classif. (of this page) } \\
\text { Unclassified }\end{array}$ & $\begin{array}{l}\text { 21. No. of Pages } \\
43\end{array}$ & 22. Price \\
\hline
\end{tabular}

Form DOT F 1700.7 (8-72) 
Copyright (C) 2022

\section{by Mineta Transportation Institute}

All rights reserved.

DOI: $10.31979 / \mathrm{mti} .2022 .2012$

Mineta Transportation Institute College of Business

San José State University

San José, CA 95192-0219

Tel: (408) 924-7560

Fax: (408) 924-7565

Email: mineta-institute@sjsu.edu

transweb.sjsu.edu/research/2012 


\section{ACKNOWLEDGMENTS}

The author is grateful to the Transportation Secure Data Center for providing access to the confidential version of the 2010-2012 California Household Travel Survey data via their secure portal. The author would like to thank the student assistant of this research project, Shivani Sidigidda, for her help with data collection. The author would also like to thank the Fresno State Transportation Institute, particularly Dr. Aly Tawfik and Rebecca Kaaz, for their support. 


\section{CONTENTS}

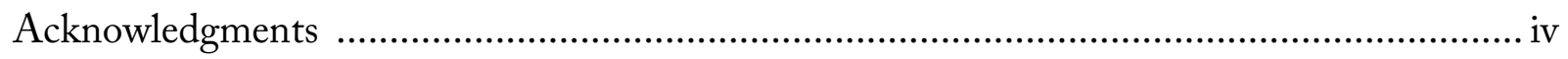

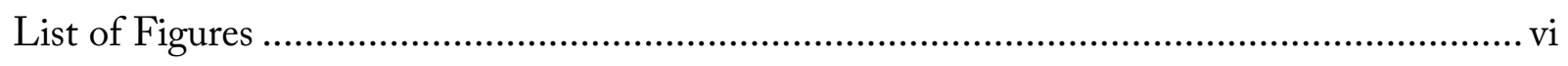

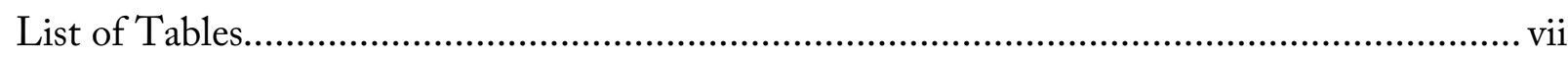

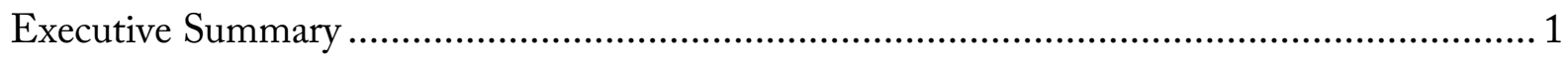

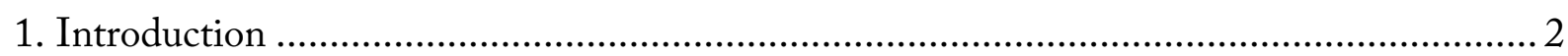

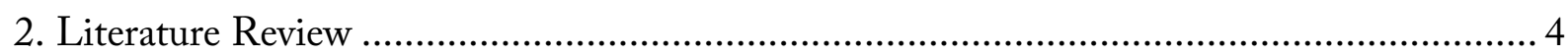

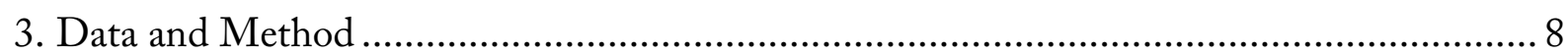

3.1 Study Area and Analysis Unit...................................................................... 8

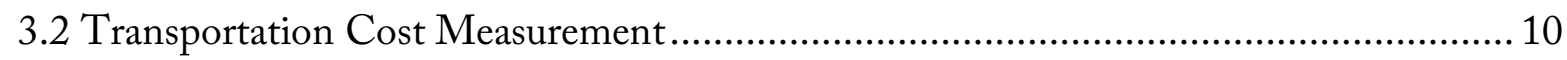

3.3 Propensity Score Matching............................................................................ 13

3.4 Balancing Treatment and Control Groups ........................................................ 14

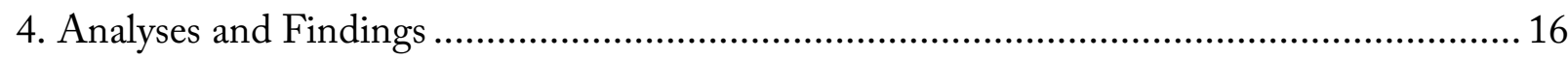

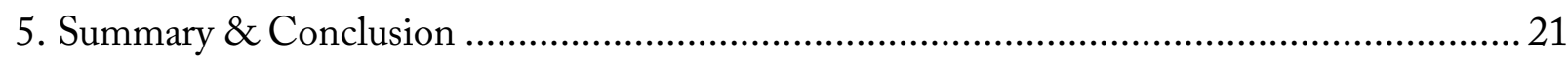

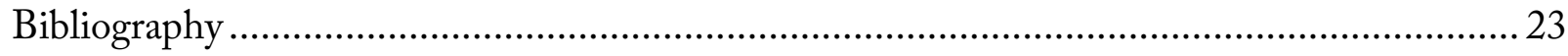

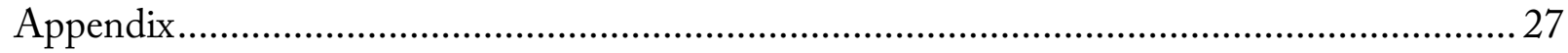

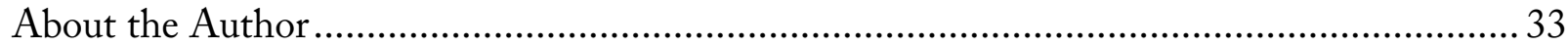




\section{LIST OF FIGURES}

Figure 1. Rail Transit Stations in the Four Californian Metropolitan Regions...................... 9 


\section{LIST OF TABLES}

Table 1. Comparison between TOD and non-TOD households .......................................... 10

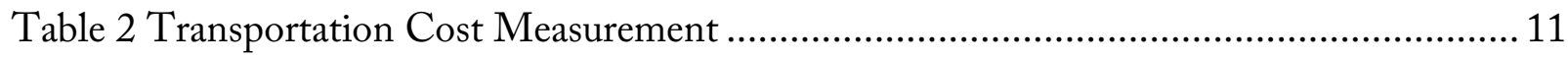

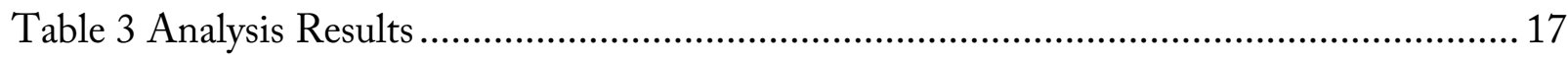

Table A. Identify Control Group to Compare Vehicle Ownership ………….........................2 27

Table B. Identify Control Group to Compare Vehicle Fuel Efficiency ………........................2 28

Table C. Identify Control Group to Compare VMT ............................................................2 29

Table D. Identify Control Group to Compare Vehicle Ownership Cost................................... 30

Table E. Identify Control Group to Compare Vehicle Operating Cost ................................... 31

Table F. Identify Control Group to Compare Transit Cost...................................................... 32 


\section{Executive Summary}

By using the data from the confidential version of the 2010-2012 California Household Travel Survey (CHTS) along with several other data sets of vehicle sales prices and fuel efficiency, this study evaluates the impact of transit-oriented development (TOD) on household transportation expenditures in the four largest California metropolitan regions: the San Francisco Bay area, the greater Los Angeles region, the San Diego metropolitan area, and the Sacramento metropolitan area. The study estimates transportation expenditures at the individual household level and breaks down household transportation expenditures into sub-categories such as vehicle ownership cost, vehicle operating cost, and transit cost. The study quantifies the impacts of TOD on household transportation expenditures by comparing TOD households with two groups of control households that are identified by propensity score matching. The first control group consists of non-TOD households that are very similar to TOD households by socio-demographic variables. The second control group consists of non-TOD households similar to TOD households by both socio-demographic characteristics and neighborhood environment and location.

The study shows that households living in TODs are significantly different from households who live outside of TODs in terms of household demographics and neighborhood environment. They tend to own fewer but more fuel-efficient cars, drive fewer miles, and use transit more. The transportation expenditures of the typical TOD household are about $40 \%$ lower than the typical non-TOD household. When controlling for household demographics, TOD households own fewer and more fuel-efficient cars, drive fewer miles, and use transit more. On average, they save $\$ 1,232$ per year on transportation expenditures compared to non-TOD households with similar demographics, accounting for $18 \%$ of their total annual transportation expenditures. When controlling for both demographics and neighborhood environment, TOD households still own slightly fewer and more fuel-efficient cars and use transit more, but they drive fewer miles compared to non-TOD households. TOD households save $\$ 429$ per year on transportation expenditures compared to non-TOD households with similar demographics and neighborhood environment, accounting for about $6 \%$ of their total annual transportation expenditures. This study confirms that Californian households save money on transportation costs by living in TODs. TOD households save money on transportation costs mainly because they own fewer cars than non-TOD households. About two-thirds of the savings can be attributed to transit-friendly neighborhood environment and one-third to access to rail transit, suggesting the importance of integrating a rail transit system with supportive land use planning and neighborhood design. 


\section{Introduction}

The concept of location affordability has gained in popularity among transportation and housing researchers, planners, and advocates in the past decade. The core idea of location affordability is that when evaluating the affordability of a neighborhood, one should consider both housing and transportation costs, the two largest expenses of the average American family (Bureau of Labor Statistics, 2018). Incorporating transportation costs into affordability measurement became a particularly important issue for advocates of transit-oriented developments (TODs) around rising concerns of transit-induced gentrification (Dawkins and Moeckel, 2016; Khan, 2007, Zuk et al., 2018). Many studies have shown that a TOD tends to increase property values (Bartholomew and Ewing, 2011; see Ibraeva et al., 2020 for a comprehensive literature review), signaling the viability and popularity of TOD projects in the real estate market. The property-value-added effects of a TOD, however, may create an affordability paradox: low-income households who are more reliant on public transit cannot afford to live close to transit (Dong, 2017). This is particularly a concern in Californian cities where low- and middle-income families are already heavily burdened by housing costs (Buhayar and Cannon, 2019). Advocates, researchers, and elected officials in California are debating whether TOD could be an effective tool to mitigate the housing affordability problem by increasing housing supply and reducing transportation costs in transit-rich neighborhoods (Dougherty, 2020). The purpose of this study is to answer these questions by comparing the transportation costs between TOD households and similar non-TOD households that are identified via propensity score matching in the four largest California metropolitan areas: the San Francisco Bay region, the greater Los Angeles region, the San Diego metropolitan area, and the Sacramento metropolitan area.

Previous research has been inconclusive on whether TODs could help to save transportation costs and improve locational affordability, and if so, to what extent. On the one hand, numerous studies show that residents in TODs tend to own fewer private cars and drive fewer miles (e.g., Holtzclaw et al., 2002; Cervero and Arrington, 2008; Cervero and Ewing, 2010; and Ibraeva et al., 2020). While these studies do not directly evaluate transportation costs, it seems reasonable to infer that residents in TODs spend less on transportation than those who live outside of TODs. Some studies that directly model transportation costs seem to confirm that residents living in compact and transit-oriented neighborhoods save money on transportation costs (Haas et al., 2016; Hamidi et al., 2016; Mudigonda et al. 2014; Rene et al., 2016). On the other hand, some studies found very weak or no evidence that residents in transit-rich neighborhoods own fewer private cars, drive fewer miles, and spend less on transportation (Deka, 2002; Lund, 2006; Smart and Klein, 2018). Access to transit and transportation cost savings do not seem to be a top priority when individual families consider which neighborhoods to move to (Lund, 2006; Tremoulet et al., 2016). 
By using data from the confidential version of the 2010-2012 California Household Travel Survey (CHTS), this study compares the transportation costs of individual households living in TODs with a control group of non-TOD households that are identified via propensity score matching. We draw data from several sources to build a database of vehicle fuel efficiency and purchase prices, which allows this study to decompose transportation expenditures at the individual household level into a few sub-categories such as vehicle ownership costs, operating costs, and transit cost; we then compare each item between TOD and non-TOD households. The decomposition of transportation costs helps us to understand how exactly TODs influence transportation costs.

The report is organized as follows: Section 2 introduces the conceptual framework of this study and reviews previous studies, Section 3 describes the data and methods, Section 4 presents the main findings of this study, and Section 5 concludes and discusses policy implications. 


\section{Literature Review}

This study evaluates the impacts of TODs on transportation costs by breaking down household transportation expenses into three items: auto ownership cost, auto operating cost, and transit cost. Living in a TOD could influence these three cost items via four basic mechanisms: car ownership, type of vehicle owned (particularly purchase price and fuel efficiency), vehicle miles traveled (VMT), and transit use. Note that the focus of this study is the financial costs of transportation, and the time cost is not included. In the following, we review previous research that has examined the impacts of TOD on these four factors as well as previous studies that directly evaluate the impacts of TOD on transportation costs.

Living in TODs could reduce residents' needs for private cars as they have better access to other travel modes, particularly public transit. A study in the Chicago, Los Angeles, and San Francisco regions shows that both residential density and access to public transit are positively correlated with lower levels of auto ownership and VMT (Holtzclaw et al., 2002). Deka (2002) uses travel survey data to examine the relationship between transit availability and vehicle ownership in Los Angeles. His research suggests a statistically significant and negative association between transit access and vehicle ownership, but the magnitude of the association is rather small. Chatman (2013) studies the per-capita car ownership of residents living in new housing within walking distance of rail transit in northern New Jersey. His research finds that residents living closer to rail transit stations tend to own fewer cars. The association between rail transit proximity and lower per-capita car ownership, however, is mainly explained by the variables that measure parking space availability, neighborhood physical environment, and household demographics, not proximity to rail transit. A study of the light rail transit in the Minneapolis-St. Paul reports a similar finding: light rail transit does not show a significant impact on car ownership once neighborhood design and self-selection bias are controlled for in the model (Cao and Cao, 2014).

Many previous studies use the structural equation model to estimate the impacts of TODs on both car ownership and VMT because "car ownership mediates the relationship between the built environment and car use" (Van Acker and Witlox, 2010). Most existing research reports a statistically significant effect of urban form and transit accessibility on the reduction of vehicle ownership and VMT, but the magnitude of the effects varies widely among these studies. For example, a study of 114 American urban areas by Bento et al. (2003) reports significant but rather small impacts of urban form and transit supply on auto travel and only some measures of urban form (e.g., population centrality) influence VMT via car ownership; however, a household-level study by Holtzclaw et al. (2002) conducted in three large American cities (Chicago, Los Angeles, and San Francisco) suggests a larger role of neighborhood environment and transit in determining vehicle ownership and travel. Neighborhood residential density and transit accessibility can explain about one-third of the variations of household VMT after controlling for income and household 
size (Holtzclaw et al., 2002). A study by Ewing et al. (2013) in 315 American urbanized areas suggests that the indirect impact of transit on VMT via land use is about three times larger than its direct impact through transit ridership. A study based on household travel survey data in the Washington, D.C. and Baltimore areas shows that TODs reduce VMT by $38 \%$ and $21 \%$ in the two regions, respectively (Nasri and Zhang, 2014). Cervero and Arrington (2008) surveyed 17 TOD housing projects in five American metropolitan areas and found that auto trip generation rates in TODs are 44\% lower than the rates suggested by the ITE Trip Generation Manual. Unfortunately, their study does not report VMT reduction in TODs.

Several studies suggest that the impacts of transit accessibility on vehicle use depend on other factors such as household demographics, neighborhood environment, and transit station design. Because lower-income residents already own fewer cars and are more reliant on public transit (Glaeser et al., 2008), moving into a more transit-oriented neighborhood may have a large impact on higher-income residents in terms of VMT reduction (Chatman et al., 2019). Transit station design mediates the relationship between transit access and travel mode choice and demand. As mentioned earlier, Chatman (2013) shows that to reduce vehicle ownership and auto use, proximity to rail transit plays a much smaller role than other built-environment factors such as housing type and tenure, parking availability, sub-regional density, and bus service. Duncan (2019) examines how park-and-ride facilities in light rail transit stations in Charlotte, North Carolina influence auto travel. He predicts that replacing park-and-ride facilities with transit-oriented design (e.g., dense housing), particularly in station areas that are underutilized or proximate to the city center, has the potential to reduce VMT. In their national study of more than 4,000 fixed-route transit stations in the United States, Renne et al. (2016) differentiate TOD from TAD (transit-adjacent development) based on walkability and residential density in station areas and show that TODs are associated with lower transportation costs than TADs.

The number of studies that directly measure the impacts of TODs on transportation costs is much smaller than the number of studies that evaluate the impact of TODs on travel behavior. This is likely because household-level transportation expenditure data at fine spatial scales are rare and hard to obtain. Most existing studies of household transportation costs have to build models to make an estimate instead of directly calculating transportation costs at the individual or neighborhood level (Smart and Klein, 2018). A good example is the Location Affordability Index (LAI) that was released by the U.S. Department of Housing \& Urban Development (n.d.), which provides estimates of housing and transportation costs at the Census block group level (Version 2) and Census tract level (Version 3) based on a structural equation model. A case study in Chicago based on the LAI (Version 2) shows that an increase of residential density is associated with more transit use and less transportation expenditures, which offset the increase of rent (Haas et al., 2016). The LAI offers a valuable tool for researchers and planners to evaluate how the changes of the built environment and transportation infrastructure might influence 
neighborhood affordability, but it has its limitations due to data constraints. Ganning (2017) shows that the LAI (Version 2) suffers from data accuracy and reliability issues and suggests a re-estimate of the index at the Census tract level (the latest third version of LAI is available at the Census tract level).

Regional household travel survey data provide researchers with another way to estimate transportation cost at the individual household level. A regional household travel survey data set contains detailed one-day or multiple-day travel records of sampled households as well as the information of vehicles and household demographics. Because a travel survey usually does not ask respondents about their expenditures on transportation, researchers have to estimate each household's transportation expenditures based on their car ownership, VMT, and transit use. Hamidi et al. (2016) compile a 15-region household travel survey database to estimate transportation costs for households in Department of Housing and Urban Development (HUD) affordable housing projects. Their study shows typical low-income households which have qualified for HUD rental assistant spend about $15 \%$ of their income on transportation, and the shares of transportation costs in household income vary widely across different regions (being much lower in transit-oriented dense areas and a lot higher in rural and auto-oriented areas). Zhou and Zolnik (2013) use the data from a travel survey in San Francisco to estimate and compare transportation costs for households in TODs and outside of TODs. Their study shows that the effect of TOD on transportation costs is statistically significant, but the magnitude of the effect is rather small: about $2.4 \%$ of average household transportation costs.

TOD residents may spend more money on public transit even though they could save money on vehicle transportation. Several studies show that TOD residents use public transit more than residents who live outside of TODs. A study of survey data from employment sides in San Francisco finds that employment sites that are closer to rail transit stations demonstrate significantly higher rates of transit use for commuting trips (Dill, 2003). A survey of residents in four rail transit stations in Portland, Oregon also shows that TOD residents use transit more than typical residents in the city, but they are not dependent on transit (Dill, 2008). Park et al. (2018) examine the impacts of TOD on travel behavior in eight American metropolitan areas and find a strong association between transit availability and transit use.

Smart and Klein (2018) conduct one of the few longitudinal studies that are based on the data obtained in the Panel Study of Income Dynamics, which directly measured household expenditures on transportation. Their study shows that household transportation costs do not change systematically when families move from transit-poor neighborhoods to transit-rich neighborhoods. They conclude that prior studies of location affordability may have over-estimated the financial benefits of living in TOD neighborhoods. 
In summary, many studies suggest TOD residents have the effects of reducing vehicle ownership and car use, though the magnitude of the effects varies widely across different studies. Several factors, such as household demographics, neighborhood environment, station design, and parking availability, could cause variation in the effects of public transit on vehicle ownership and auto travel. The number of studies of household transportation expenditures is relatively smaller because of data constraints. Typical regional travel survey data include detailed travel and vehicle records but lack detailed information that is required to calculate transportation costs, such as vehicle purchase prices, fuel efficiency, maintenance fees, and transit fare/pass prices, forcing researchers to use rough estimates in their models. Though most model-estimates suggest that TODs reduce household transportation expenses, a longitudinal study (Smart and Klein, 2018) based on reported household transportation expenditure finds no such effect at all. The inconsistent and even contradictory findings from previous studies warrant further exploration of the impact of TODs on household transportation costs.

This study partially fills this gap by comparing the transportation costs of households in TODs in four of the largest Californian metropolitan areas with comparable non-TOD households that are identified through propensity score matching. We build a database of vehicle purchase prices, vehicle fuel efficiency, and transit fare prices that allows for a more detailed and accurate calculation of household transportation costs. Low- and middle-income residents in large Californian metropolitan areas are heavily burdened by housing costs. Advocates, researchers, and elected officials in California are debating whether TOD could be an effective tool to mitigate the housing affordability problem by increasing housing supply and reducing transportation costs in transit-rich neighborhoods (Dougherty, 2020). This study contributes to this debate by providing more accurate estimates of potential savings in transportation costs in TOD neighborhoods in the four largest Californian metropolitan areas. 


\section{Data and Method}

\subsection{Study Area and Analysis Unit}

The primary data source of this study is the confidential version of the 2010-2012 California Household Travel Survey (CHTS) data that we accessed through a remote secure portal environment maintained by the Transportation Secure Data Center. The present study focuses on rail transit stations in California's four largest metropolitan regions in which almost all California's rail transit stations are located. The four regions include the San Francisco Bay Area (including the San Francisco, San José, and Santa Rosa metropolitan areas), the greater Los Angeles region (including the Los Angeles, Riverside, and Oxnard metropolitan areas), the San Diego metropolitan area, and the Sacramento metropolitan area. Among the 42,436 surveyed households in the 2010-2012 CHTS data, 27,900 of them are located in these four regions.

This analysis is conducted at the household level. The 2010-2012 CHTS dataset contains several variables that describe the demographic characteristics of individual households such as household size, income, homeownership, dwelling type, and the numbers of workers and drivers within each household. We aggregate the education variables at the person level to the household level to create a variable that indicates whether at least one household member has a college education or higher degree. The XY coordinates of home addresses allow us to geocode all households at the point level and match them to Census block groups (hereafter referred to as neighborhoods). We then create a few variables to represent the neighborhood environment. We measure neighborhood density as the number of residents and workers per acre of land. We calculate a ratio between the number of personal service jobs (food, retail, recreation, and accommodation) and population in a neighborhood to measure the level of mixed land use and potential daily travel destinations within a neighborhood. The median household income is used to represent the socioeconomic status of a neighborhood. We use the distance between a neighborhood and the city center to represent its regional accessibility. The data that we use to measure neighborhood environment are from the American Community Survey (2014-2018) data downloaded from the National Historical Geographic System (Manson et al., 2020) and the Census Longitudinal Employer-Household Dynamics data (United States Census Bureau, n.d.).

As shown in Figure 1, we identify 702 rail transit stations operating in the four Californian regions and use 694 of them after excluding two funicular stations and 12 airport rail link stations. Among the 27,900 surveyed households in the four regions, only 2,225 of them (about 8.0\%) live within a half mile of these rail transit stations (these households are hereafter referred to as TOD households), and 25,675 households live outside of rail transit service areas (hereafter referred to as non-TOD households). 
Figure 1. Rail Transit Stations in the Four Largest Californian Metropolitan Regions

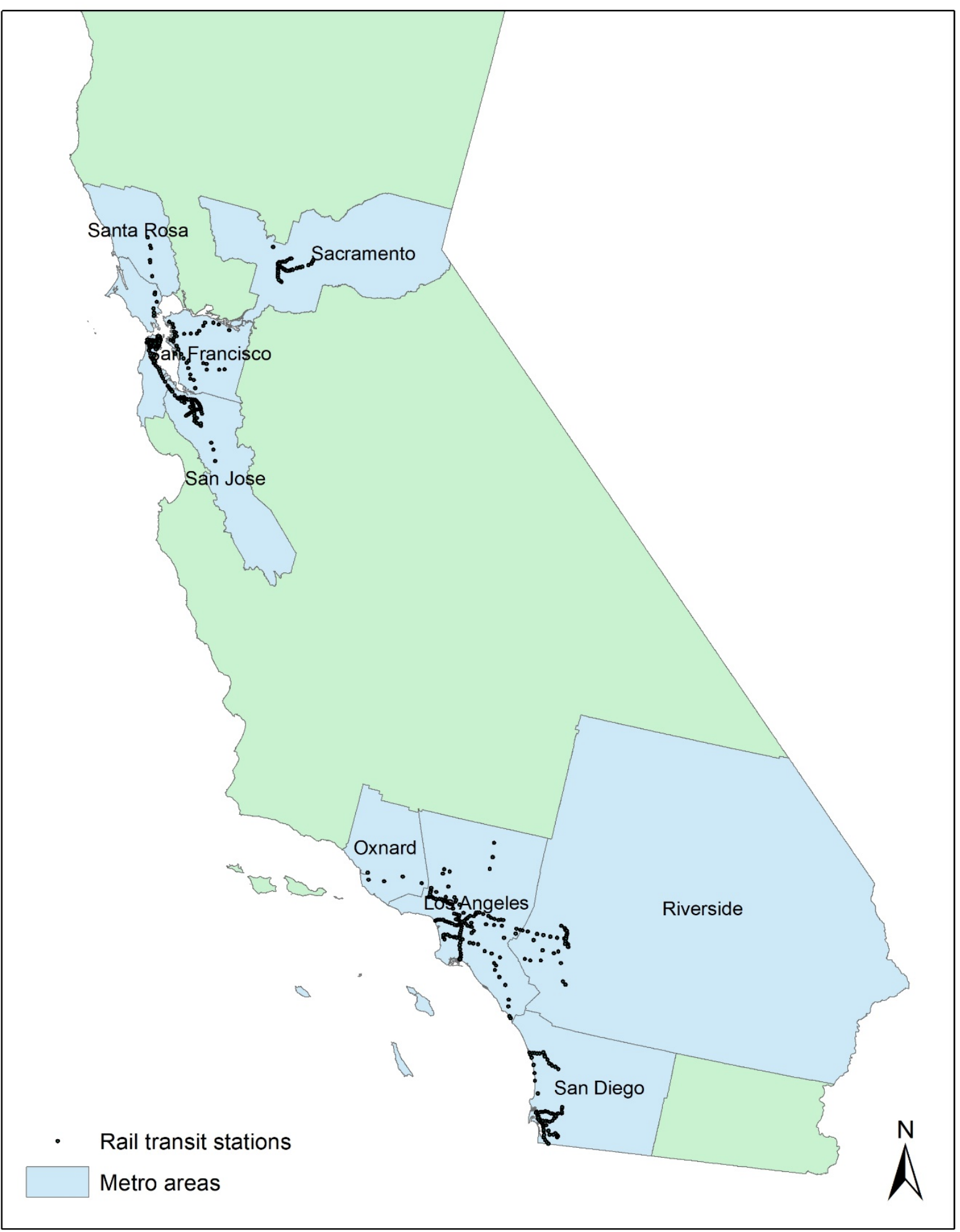

We compare TOD households with non-TOD households in Table 1, which reveals that TOD households are smaller ( 2.24 vs. 2.63 persons) with fewer drivers (1.52 vs. 1.91) and workers (1.19 
vs. 1.28), on average. TOD households tend to have lower incomes. The education attainment levels of TOD households is slightly lower than that of non-TOD households. Much larger differences between TOD and non-TOD households can be observed in housing and neighborhood environment. TOD households have a much lower level of homeownership (52.1\% vs. 78.5\%), and compared to non-TOD households (74.0\%), fewer TOD households live in singlefamily homes (37.5\%). The neighborhoods of TOD households demonstrate higher density (58.98 vs. 16.63 persons and jobs per acre), greater levels of mixed land use (0.24 vs. 0.09$)$, and a proximity to $\mathrm{CBD}$ (7.60 vs. 19.42 miles). Among the four Californian regions, about $60 \%$ of TOD households resided in the San Francisco Bay, two times higher than the proportion of non-TOD households who lived in the Bay Area (29.9\%).

Table 1. Comparison between TOD and Non-TOD Households

\begin{tabular}{|c|c|c|c|c|}
\hline & \multicolumn{2}{|c|}{ TOD households } & \multicolumn{2}{|c|}{ Non-TOD households } \\
\hline & $\mathrm{N}^{*}$ & Mean & $\mathrm{N}^{*}$ & Mean \\
\hline Household size & 2225 & 2.240 & 25675 & 2.631 \\
\hline Number of drivers in household & 2225 & 1.521 & 25675 & 1.909 \\
\hline Number of workers in household & 2225 & 1.189 & 25675 & 1.280 \\
\hline Household income $<\$ 25 \mathrm{~K}$ (yes $=1$ ) & 2044 & 0.205 & 23238 & 0.136 \\
\hline Household income $\$ 25 \mathrm{k}-\$ 50 \mathrm{~K}(\mathrm{yes}=1)$ & 2044 & 0.193 & 23238 & 0.183 \\
\hline Household income $\$ 50 \mathrm{k}-\$ 75 \mathrm{~K}$ (yes $=1$ ) & 2044 & 0.168 & 23238 & 0.170 \\
\hline Household income $\$ 75 \mathrm{k}-\$ 100 \mathrm{~K}$ (yes $=1)$ & 2044 & 0.128 & 23238 & 0.153 \\
\hline Household income $\$ 100 \mathrm{k}-\$ 150 \mathrm{~K}(\mathrm{yes}=1)$ & 2044 & 0.155 & 23238 & 0.190 \\
\hline Household income $>\$ 150 \mathrm{~K}(\mathrm{yes}=1)$ & 2044 & 0.152 & 23238 & 0.169 \\
\hline College degree $($ yes $=1)$ & 2210 & 0.633 & 25513 & 0.643 \\
\hline Homeownership (yes=1) & 2216 & 0.521 & 25606 & 0.785 \\
\hline Living in SFH (yes=1) & 2213 & 0.375 & 25632 & 0.740 \\
\hline Neighborhood density & 2218 & 58.983 & 25369 & 16.633 \\
\hline Neighborhood mixed use & 2218 & 0.242 & 25369 & 0.093 \\
\hline Neighborhood income (in $\$ 1000$ ) & 2153 & 88.909 & 25006 & 95.639 \\
\hline Distance to CBD (miles in Log) & 2218 & 7.601 & 25372 & 19.415 \\
\hline San Francisco Bay Area & 2225 & 0.600 & 25675 & 0.299 \\
\hline Greater Los Angeles Region & 2225 & 0.322 & 25675 & 0.565 \\
\hline Sacramento metropolitan area & 2225 & 0.023 & 25675 & 0.074 \\
\hline San Diego metropolitan area & 2225 & 0.055 & 25675 & 0.061 \\
\hline Assigned travel day (weekend=1) & 2225 & 0.206 & 25675 & 0.284 \\
\hline
\end{tabular}

$* \mathrm{~N}$ varies because of missing values.

\subsection{Transportation Cost Measurement}

We decompose household transportation expenditure into three items: car ownership costs, car operating costs, and transit costs. There are a few sub-items under each item, as shown in Table 2. The confidential version of the 2010-2012 California Household Travel Survey (CHTS) data 
include detailed information on vehicle ownership, including the vehicle make, model, model year, number of cylinders, and fuel type of each vehicle owned by surveyed households. The 2010-2012 CHTS data also contain auto and transit trips that each surveyed household member undertook on the assigned travel date, allowing me to calculate daily vehicle VMT and the number of transit trips per household member.

Table 2. Transportation Cost Measurement

\begin{tabular}{|c|c|}
\hline & Formula/Assumption \\
\hline \multicolumn{2}{|l|}{ Vehicle ownership costs } \\
\hline Vehicle depreciation & $\begin{array}{l}12 \% \text { of MSRP } \\
\text { years }\end{array}$ \\
\hline $\begin{array}{l}\text { Finance charge } \\
\text { (mortgage interest) }\end{array}$ & $\begin{array}{l}60 \text {-month mortgage with } 5 \% \text { APR and zero downpayment in the first five years; } \\
\text { zero after five years }\end{array}$ \\
\hline Insurance (full coverage) & flat rates for eight auto types ${ }^{2}$ as suggest by $\mathrm{AAA}^{3}$ \\
\hline Registration/renewal fee & registration, license, $\mathrm{TIF}^{4}, \&$ county/district fees based California DMV website \\
\hline \multicolumn{2}{|l|}{ Vehicle operating costs } \\
\hline Fuel cost & MPG*VMT*fuel price \\
\hline Maintanence, repair \& tires & flat rates for eight auto types ${ }^{2}$ as suggest by AAA \\
\hline Transit fare cost & weekly transit trip count*flat-rate cost per unlinked transit trip \\
\hline \multicolumn{2}{|c|}{ 1. MSRP: manufacturer suggested retail price. } \\
\hline \multicolumn{2}{|c|}{$\begin{array}{l}\text { 2. The eight types include small sedan, medium sedan, large sedan, hybrid, electric, small SUV, medium SUV, } \\
\text { and pickup. }\end{array}$} \\
\hline \multicolumn{2}{|c|}{ 3. AAA: American Auto Association. } \\
\hline 4. TIF: $\mathrm{t}$ & \\
\hline
\end{tabular}

The 2010 CHTS dataset, however, does not include several variables that are required to calculate transportation costs for each individual auto trip, such as vehicle values, vehicle fuel efficiency, and transit fare prices. To obtain information of vehicle value (measured as manufacturing suggested retail price, or MSRP) and fuel efficiency (miles per gallon, or MPG), we use Python coding to match each individual vehicle in the 2010-2012 with relevant records in a fuel-efficiency information database that is maintained by the U.S. Department of Energy and the U.S. Environmental Protection Agency (n.d.). When the MSRP and MPG information of a vehicle model is missing from this database, we use a dataset downloaded from Kaggle.com as a complement. While these two databases are large and comprehensive, they do not cover all vehicle models in the 2010-2012 CHTS dataset, particularly the vehicle models that are old (e.g., model years in the 1990s and earlier) as well as vehicle models that have a small, niche brand. To preserve the number of observations that we can use for analyses, we estimate the MSRP and MPG values for vehicle models that are not covered by the two databases based on their model type, the number of cylinders, and fuel type. The assumption is that the real value of a specific car model's 
MSPR (adjusted for inflation) and MPG remain the same over time. The 2010-2012 CHTS dataset recorded 51,551 vehicles of 27,900 survey households in the four study regions. Our final dataset contains valid MSRP and MPG information for 47,947 (93.00\%) and 46,758 (90.70\%) of the surveyed vehicles respectively.

Car ownership costs include four components: vehicle depreciation, finance charge, full-coverage insurance, and registration renewal fee. It is assumed that a car loses $12 \%$ of its value (MSRP) each year in the first five years and $8 \%$ per year in the next five years. The finance charge is the annual interest payment of a 60 -month car mortgage with a $5 \%$ interest rate and zero down payment. The mortgage covers the purchase price (MSRP) as well as the sales tax, license fee, and registration fee. Together, the last three items account for about $10 \%$ of the purchase price in California. The insurance cost of a vehicle is based on the full coverage insurance rates for eight vehicle types suggested by the American Auto Association (AAA, n.d.). Vehicle body types in the 2010-2012 CHTS dataset are not exactly coded as AAA's eight typical vehicle types, and I recoded them to match with AAA's eight typical vehicle types. I apply an annual registration renewal fee of $\$ 350$ to each vehicle. The flat registration renewal fee is estimated based on relevant information posted at the California Department of Motor Vehicle's website, including registration fee, vehicle license fee, Transportation Improvement Fee, and county/district fee. Car ownership costs are calculated for each individual vehicle and aggregated to the household level. The car ownership cost of a household is considered incomplete if the MSRP or insurance information of one or more vehicles the household owns is missing.

Car operating costs contain two elements: fuel costs and maintenance costs (including maintenance, repair, and tire costs), both of which are a linear function of VMT. For each auto trip, the fuel (gasoline or diesel) cost is the multiplication of the fuel price and the fuel consumption of the trip, which is calculated by dividing the trip distance (shortest path distance in miles) by the fuel efficiency of the vehicle (MPG). The maintenance cost of an auto trip is determined by the trip distance and a flat rate of maintenance cost (in dollar per mile) based on vehicle type, as suggested by AAA (n.d.). The operating costs of individual auto trips are then aggregated to the household level, with an aggregate weight that represents the share of household members in the total number of occupants in the vehicle. For example, if an auto trip involves two members of a household and two members of another household, the operating cost of the trip carries a weight of 0.5 when it is counted toward each of the two households.

The costs of transit trips can be calculated in two ways. One is based on individual transit trips that were recorded on the assigned travel date for each household. The other is based on the number of transit trips in the past week reported by each surveyed person. The first method calculates transit costs of each household by aggregating individual trip costs to the household level. The 2010-2012 CHTS data recorded 10,696 transit trips. About two-thirds (66.7\%) of them were taken through the transit service provided by the 34 transit systems in the four study regions. 
The cost of each transit trip is assumed to be the fare price of a one-way transit trip as reported on these transit systems' websites. Most transit agencies offer discounts for youth and seniors. This analysis is able consider this fare variability, as the 2010 CHTS dataset reports the ages of surveyed persons. The advantage of this method is that it can take into account the prices of individual transit trips. There are, however, a few disadvantages. First, about one-third of transit trips are associated with non-typical transit services (e.g., school bus, Greyhound bus, Amtrak bus, and private and public shuttle). It is difficult to obtain or estimate the fare prices of these non-typical transit trips. Second, this analysis is not able to consider the fact that one transit ticket might be valid for more than one transit trip if subsequent trips occur within a certain time period (e.g., two hours). It also does not consider that fact that about $9.1 \%$ of survey participants possess transit passes. Last but not least, a single-day travel diary may not accurately represent transit use because most surveyed households did not use transit on daily basis. Because TOD residents tend to use transit more often, they are more likely to report transit use on a specific assigned travel date compared to non-TOD residents, leading to an overestimation of transit costs for TOD residents.

The second method relies on weekly counts of transit trips, which may be more accurate. The transit systems associated with these trips were not reported in the data, making it impossible to take into account the prices of individual transit trips. Following Hamidi et al. (2016), we downloaded the data of annual unlinked transit trips and fare revenues of the 25 transit agencies in the four study regions from the National Transit Database (Federal Transit Administration, n.d.). We sum up the number of unlinked transit trips and fare revenues across the 25 transit agencies and calculate the average fare price of one unlinked transit trip, which is about $\$ 1.10$. The cost of each transit trip is thus assumed to be $\$ 1.10$ and is aggregated to the household level. In the following analyses, we present the results from the second method.

\subsection{Propensity Score Matching}

This study evaluates the impacts of TOD on household transportation expenditures by comparing TOD households with control households. As shown earlier, typical TOD households are systematically different from non-TOD households. They tend to be smaller and less affluent than non-TOD households. They are also more likely to live in multifamily homes in urban neighborhoods with proximity to city centers. It is thus inappropriate to evaluate the impact of TOD by directly comparing TOD households with non-TOD households.

This study utilizes propensity score matching to identify control households that are very similar to TOD households based on the variables in Table 1. The assumption is that if TOD households (the treatment group) are very similar to non-TOD households in the control group, their differences in transportation expenditures are likely due to their access to rail transit. The outcome variables that we would like to compare between the treatment and control groups include the three components of household expenditure costs: vehicle ownership cost, vehicle operating 
cost, and transit cost. We also compare vehicle ownership, vehicle fuel efficiency, and VMT between the groups of households to understand why the two groups are different (or similar) in terms of transportation expenditures.

For each outcome variable, we identify two control groups. One is based on a narrowly-defined TOD concept: access to rail transit, meaning that a rail-transit-served neighborhood could be transit-friendly or only transit-adjacent (Renne, 2008). The control group is required to be similar to the treatment group by demographic variables only. The other is based on a comprehensively defined TOD concept: access to rail transit and supportive neighborhood environment (Calthorpe, 1993; Dong, 2016). The control group has to be similar to the treatment group in terms of household demographics as well as neighborhood environment and location. The comparisons of one outcome variable based on the two control groups allow us to evaluate the extent to which neighborhood environment and location matter for the money-saving effect of TODs.

We use the open-source software R's "MatchIt" package (Ho et al., 2011) to conduct propensity score matching. A logistic regression uses the household, neighborhood, and locational variables in Table 1 to predict whether a household lives in a TOD. The predicted probability of living in TODs (the propensity score) is used to match TOD households with non-TOD households via the one-to-one nearest neighbor approach. To ensure high-quality matching, the matching requires a non-TOD household to be within a caliper distance (set as 0.2 following Austin, 2011) in order to be matched with a TOD household. The results suggest that most of the unmatched TOD households are those that live in central-city neighborhoods with extremely high density (e.g., neighborhoods in downtown San Francisco). This reflects the fact that rail-transit-served neighborhoods in central cities are unique in terms of their location and built environment, and it is difficult to find very similar neighborhoods that are not served by rail transit.

\subsection{Balancing Treatment and Control Groups}

The main object of propensity score matching is to balance the distribution of potentially cofounded covariates for TOD and non-TOD households. We use two measurements to assess how similar TOD households are to their control households. The first is a paired t-test of the difference of each covariate between the treatment and control groups (McNemar tests for categorical variables), which is the most commonly used measurement in the literature. One major limitation of paired t-tests is that they are sensitive to sample size. The difference of a variable between the treatment and control groups is more likely to be statistically significant when the group sizes are larger. Large sample sizes, however, are supposed to be an advantage in achieving a balance between the treatment and control groups. To overcome this issue, we calculate the standardized difference of a variable between the treatment and control groups, which is not sensitive to sample size. Following Austin (2011), a standardized difference below 0.1 is considered negligible. 
The assessments of the balance between the control and treatment groups for each outcome variable are presented in the Appendix (Tables A through F). In each Appendix table, the treatment group is compared with two control groups: one controls for household attributes only and the other controls for household characteristics, neighborhood environment, and location. The number of observations shown in each table indicates the number of TOD households that are matched with non-TOD households. Almost every TOD household can be matched with a non-TOD household when the matching is based on household attributes only. There is also a portion of TOD households that cannot be matched with non-TOD households when the matching also controls for neighborhood environment and location. As mentioned earlier, this complexity arises because it is more difficult to find similar neighborhoods for transit-rich downtown neighborhoods, particularly those in San Francisco. Even for matched TOD and nonTOD households, the matching is not always perfect. In almost each appendix table, one or two neighborhood environmental variables are still statistically different between the treatment and control groups. To mitigate this problem, we compare the outcome variable between the treatment and control groups not only by a paired t-test, but also by running a regression that controls for the covariates. 


\section{Analyses and Findings}

Table 3 presents the results of the paired t-tests and regression models that are used to compare TOD households with three groups of non-TOD households: all of the non-TOD households, a control group of non-TOD households with similar demographics, and a control group of nonTOD households with similar demographics as well as similar neighborhood environment and location. For the regression analyses, only the coefficients of the TOD dummy variable are presented, and the coefficients of control variables are not shown. In general, the results of the paired t-tests and regression analyses are quite consistent. As expected, the coefficients from the regression analyses are slightly smaller than the coefficients from the paired $t$-tests because the regression analyses further control for the covariates. The following discussions are mainly based on the coefficients yielded from the regression models.

TOD households own slightly fewer cars. On average, TOD households own about 1.24 vehicles, which is about 0.66 fewer than households living outside of TODs. The difference, however, becomes much smaller after controlling for household demographics: TOD households own 0.24 fewer cars than non-TOD households with similar demographics. The gap is even smaller after controlling for neighborhood environment and location. TOD households own 0.11 fewer vehicles than non-TOD households having similar demographic characteristics, neighborhood environment, and intra-metropolitan location. 
Table 3. Analysis Results

\begin{tabular}{|c|c|c|c|c|}
\hline & TOD & Non-TOD & $\begin{array}{c}\text { Mean } \\
\text { difference }\end{array}$ & $\begin{array}{l}\text { Regression } \\
\text { coefficient }\end{array}$ \\
\hline \multicolumn{5}{|c|}{ Pre-mached households } \\
\hline Vehicle ownership & $\begin{array}{c}1.24 \\
(\mathrm{~N}=1946)\end{array}$ & $\begin{array}{c}1.90 \\
(\mathrm{~N}=22645)\end{array}$ & $-0.66 * * *$ & \\
\hline $\begin{array}{l}\text { Fuel efficiency } \\
\text { (Gasoline, miles/gallon) }\end{array}$ & $\begin{array}{c}23.70 \\
(\mathrm{~N}=1261)\end{array}$ & $\begin{array}{c}22.50 \\
(\mathrm{~N}=17425)\end{array}$ & $1.19 * * *$ & \\
\hline $\begin{array}{l}\text { VMT } \\
\text { (miles/day) }\end{array}$ & $\begin{array}{c}37.72 \\
(\mathrm{~N}=1790)\end{array}$ & $\begin{array}{c}66.43 \\
(\mathrm{~N}=20232)\end{array}$ & $-28.70 * * *$ & \\
\hline $\begin{array}{l}\text { Vehicle ownership cost } \\
\text { (\$/year) }\end{array}$ & $\begin{array}{c}3501.99 \\
(\mathrm{~N}=1680)\end{array}$ & $\begin{array}{c}5870.95 \\
(\mathrm{~N}=18569)\end{array}$ & $-2368.96 * * *$ & \\
\hline $\begin{array}{l}\text { Vehicle operating cost } \\
\text { (\$/day) }\end{array}$ & $\begin{array}{c}7.94 \\
(\mathrm{~N}=1640)\end{array}$ & $\begin{array}{c}14.25 \\
(\mathrm{~N}=19378)\end{array}$ & $-6.31 * * *$ & \\
\hline $\begin{array}{l}\text { Transit cost } \\
\text { (\$/week ) }\end{array}$ & $\begin{array}{c}7.78 \\
(\mathrm{~N}=1934)\end{array}$ & $\begin{array}{c}5.00 \\
(22394)\end{array}$ & $2.77 * * *$ & \\
\hline
\end{tabular}

\begin{tabular}{|c|c|c|c|c|}
\hline \multicolumn{5}{|c|}{ Households matched by demographics } \\
\hline Vehicle ownership & $\begin{array}{c}1.24 \\
(\mathrm{~N}=1946)\end{array}$ & $\begin{array}{c}1.49 \\
(\mathrm{~N}=1946)\end{array}$ & $-0.25 * * *$ & $-0.24 * * *$ \\
\hline $\begin{array}{l}\text { Fuel efficiency } \\
\text { (Gasoline, miles/gallon) }\end{array}$ & $\begin{array}{c}23.70 \\
(\mathrm{~N}=1261)\end{array}$ & $\begin{array}{c}22.83 \\
(\mathrm{~N}=1261)\end{array}$ & $0.86^{* *}$ & $0.80 * * *$ \\
\hline $\begin{array}{l}\text { VMT } \\
\text { (miles/day) }\end{array}$ & $\begin{array}{c}37.72 \\
(\mathrm{~N}=1790)\end{array}$ & $\begin{array}{c}47.66 \\
(\mathrm{~N}=1790)\end{array}$ & $-9.94 * *$ & $-10.04 * * *$ \\
\hline $\begin{array}{l}\text { Vehicle ownership cost } \\
\text { (\$/year) }\end{array}$ & $\begin{array}{c}3510.35 \\
(\mathrm{~N}=1676)\end{array}$ & $\begin{array}{c}4293.17 \\
(\mathrm{~N}=1676)\end{array}$ & $-782.82 * *$ & $-750.16^{* * *}$ \\
\hline $\begin{array}{l}\text { Vehicle operating cost } \\
(\$ / \text { day })\end{array}$ & $\begin{array}{c}8.15 \\
(\mathrm{~N}=1636)\end{array}$ & $\begin{array}{c}10.88 \\
(\mathrm{~N}=1636)\end{array}$ & $-2.72 * *$ & $-1.71 *$ \\
\hline $\begin{array}{l}\text { Transit cost } \\
\text { (\$/week ) }\end{array}$ & $\begin{array}{c}8.56 \\
(\mathrm{~N}=1934)\end{array}$ & $\begin{array}{c}5.75 \\
(\mathrm{~N}=1934)\end{array}$ & $2.80 * *$ & $2.74 * * *$ \\
\hline
\end{tabular}

Households matched by demographics, neighborhood environment, \& location

\begin{tabular}{|l|c|c|c|c|}
\hline Vehicle ownership & $\begin{array}{c}1.35 \\
(\mathrm{~N}=1626)\end{array}$ & $\begin{array}{c}1.48 \\
(\mathrm{~N}=1626)\end{array}$ & $-0.13^{* * *}$ & $-0.11^{* * *}$ \\
\hline $\begin{array}{l}\text { Fuel efficiency } \\
\text { (Gasoline, miles/gallon) }\end{array}$ & $\begin{array}{c}23.72 \\
(\mathrm{~N}=1129)\end{array}$ & $\begin{array}{c}23.17 \\
(\mathrm{~N}=1129)\end{array}$ & $0.55^{* *}$ & $0.47^{*}$ \\
\hline $\begin{array}{l}\text { VMT } \\
(\text { miles/day) }\end{array}$ & $\begin{array}{c}41.31 \\
(\mathrm{~N}=1484)\end{array}$ & $\begin{array}{c}42.20 \\
(\mathrm{~N}=1484)\end{array}$ & -0.89 & -0.43 \\
\hline $\begin{array}{l}\text { Vehicle ownership cost } \\
(\$ / \text { year })\end{array}$ & $\begin{array}{c}3820.67 \\
(\mathrm{~N}=1382)\end{array}$ & $\begin{array}{c}4196.17 \\
(\mathrm{~N}=1382)\end{array}$ & $-375.50^{* *}$ & $-310.84^{* * *}$ \\
\hline $\begin{array}{l}\text { Vehicle operating cost } \\
(\$ / \text { day })\end{array}$ & $\begin{array}{c}8.76 \\
(\mathrm{~N}=1376)\end{array}$ & $\begin{array}{c}8.96 \\
(\mathrm{~N}=1376)\end{array}$ & -0.20 & 0.48 \\
\hline $\begin{array}{l}\text { Transit cost } \\
(\$ / \text { week })\end{array}$ & $\begin{array}{c}7.22 \\
(\mathrm{~N}=1619)\end{array}$ & $\begin{array}{c}7.04 \\
(\mathrm{~N}=1619)\end{array}$ & $1.18 * *$ & $1.10^{* *}$ \\
\hline
\end{tabular}

*significant at the $10 \%$ level, ** significant at the $5 \%$ level, and ***significant at the $1 \%$ level 
The vehicles owned by TOD households are slightly more fuel-efficient. Note that the number of observations for this comparison is relatively small (1,261 out of 2,225 TOD households). This is because in order to ensure that the comparison is apples to apples, we compare households who own only gasoline cars and exclude households who own diesel cars or vehicles using alternative fuels. We also have to exclude households that do not own any vehicles and households with missing values in vehicle attributes. The results show that vehicles owned by TOD households are more efficient than typical cars owned by non-TOD households by 1.19 MPG. Again, the difference is attenuated after controlling for household demographics (0.80 MPG) and even smaller after controlling for neighborhood environment and location (0.47 MPG).

TOD households do not seem to drive appreciably fewer miles than control households. When we compare a typical TOD household with an average non-TOD household, we find that TOD households drive fewer miles (28.71 miles per day). The difference becomes smaller (10.04 miles per day) but remains statistically significant when we compare TOD households with non-TOD households with similar demographics. The gap becomes statistically insignificant after controlling for neighborhood environment and location.

TOD households save money on car ownership, which is largely consistent with the finding that they tend to owner fewer cars. On average, a TOD household spends $\$ 2,369$ less than non-TOD households per year on vehicle ownership. A comparison between TOD and non-TOD households with similar demographics suggests that TOD households can save $\$ 750$ per year on vehicle ownership costs. The saving is further reduced to $\$ 311$ per year after neighborhood environment and location are controlled for.

To understand the structure of the vehicle ownership costs for TOD households, we calculate the share of each ownership cost item. The calculation indicates that for TOD households who own at least one vehicle, vehicle depreciation and insurance are the two largest items in their vehicle ownership costs, account for $45 \%$ and $40 \%$ respectively. About $20 \%$ of the vehicles they own are five-years-old or newer and require interest payments.

TOD households do not seem to save money on vehicle operating costs after controlling for all the covariates. This is unsurprising given that they drive about the same number of miles as control households. Specifically, the average daily vehicle operating cost of a typical TOD household is merely more than a half of that of a typical non-TOD household (\$7.94 vs. \$14.25). The amount saved is reduced to $\$ 1.71$ per day after controlling for household demographics and becomes close to zero after neighborhood environment and location are considered.

TOD households spend more on transit fares (including both bus and rail transit). A typical TOD and non-TOD household spend about $\$ 7.78$ and $\$ 5.00$ per week on transit fares respectively, meaning that TOD households spend $\$ 2.77$ more per week. When we compare TOD and non-TOD households with similar demographics, the difference is similar: TOD households 
spend about $\$ 2.74$ more per week. The extra money that TOD households spend on transit fares is only $\$ 1.10$ per week in comparison with households who have similar demographics and live in similar neighborhoods and locations.

To compare the total annual transportation costs of TOD and non-TOD households, we convert the daily vehicle operating costs and weekly transit costs to their annual terms. On average, the annual transportation costs of TOD and non-TOD households in the four largest Californian metropolitan regions are about $\$ 6,804$ and $\$ 11,332$, respectively accounting for about $10 \%$ and $17 \%$ of the state median household income (\$66,605 in 2010). The transportation expenditures of a typical TOD household are about $40 \%$ lower than those of a typical non-TOD household. For TOD households, about $52 \%$ of their transportation expenditures occur because of vehicle ownership, $43 \%$ because of vehicle operation, and $6 \%$ because of transit use.

Compared with non-TOD households with similar demographics, TOD households save at least $\$ 1,232$ per year on transportation expenditures, accounting for $18 \%$ of their total transportation expenditures. Compared with non-TOD households with similar demographics and neighborhood environment and location, they save about $\$ 429$ per year. TOD households save money on transportation costs mainly because they own fewer cars than non-TOD households. Overall, living in transit-friendly neighborhoods with access to rail transit can save at least $\$ 1,232$ transportation costs for TOD households. About 35\% $(\$ 429 / \$ 1,232)$ of the savings can be attributed to access to rail transit and the other $65 \%$ are attributed to transit-friendly neighborhood environment and location.

Before proceeding to draw final conclusions, it is worth noting a few limitations of this study. As mentioned earlier, not all TOD households are matched with similar non-TOD households when the matching controls for both demographic and neighborhood variables. It is difficult to match TOD households living in extremely high-density downtown neighborhoods with non-TOD households. Compared with TOD households that can be matched with non-TOD households by both demographic and neighborhood variables, unmatched TOD households own fewer vehicles ( 0.67 vs. 1.35 vehicles per household), their vehicles are more fuel-efficient (23.48 vs. 23.72 MPG), and they drive fewer miles (20.31 vs. 41.31 miles per day). Correspondingly, they spend less money on vehicle ownership ( $\$ 2,024$ vs. $\$ 3,821$ per year), save money on vehicle operation cost ( $\$ 1,088$ vs. $\$ 3,197$ per year), and pay more to use transit ( $\$ 534$ vs. $\$ 459$ per year). Overall, the average annual transportation expenditure for unmatched TOD households is $\$ 3,645$, much lower than that of the matched TOD households $(\$ 7,477)$. Without appropriate control households, it is difficult to know exactly how much these unmatched TOD households save on transportation costs.

Another major limitation of this study, as discussed earlier, is that the estimates of transportation expenditures rely on some assumptions (e.g., that California households buy cars by taking out of 
60 -month loans with a $5 \%$ interest rate and zero down payment). In addition, when matching TOD households with non-TOD households, this study is not able to control some variables that could play a role in determining the impacts of TOD on household transportation expenditure (e.g., bus service and parking space availability) because of data constraints. 


\section{Summary \& Conclusion}

This study utilizes the confidential version of the 2010-2012 CHTS data along with several data sources of vehicle sales prices and vehicle fuel efficiency to estimate the impacts of TOD on household transportation expenditures in the largest four California metropolitan regions. The estimation is done by comparing TOD households with two control groups of non-TOD households identified through propensity score matching. One is similar to the TOD households by household demographics only, and the other is similar to the TOD households in terms of both demographics and neighborhood environment and location.

Before proceeding to discuss the major findings from this study, it is important to mention that this study focused on transportation cost, but did not estimate the impact of TOD on property values and rental prices. As discussed at the beginning of this report, housing and transportation costs are the two largest expenditure items for a typical American family. Research shows that TOD could increase property values and rental prices, making TOD neighborhoods less affordable. The overall impact of TOD on neighborhood affordability thus depends on whether the transportation cost savings exceed the potential increase of housing costs caused by TOD. Another limitation of this study is that it analyzed the impacts of one specific transit mode: rail transit. Bus transit and non-motorized transit also have the potential to reduce car use and save transportation costs. As shown in this analysis, the impact of the built environment could exceed the effect of transit infrastructure on people's travel behavior. Lastly, the COVID-19 pandemic causes great uncertainty about the future of public transit and the potential benefits of TOD as many workers shifted to work from home. Some transit users have switched to cars because of the fear of infection. It remains to be seen whether the impact of the COVID-19 pandemic is temporary.

The analysis shows that the transportation expenditures of TOD households are very different from those of typical households who live outside of TODs. Their transportation expenditures are $40 \%$ lower than the transportation expenditures of non-TOD residents. A large portion of the difference, however, is explained by their different demographic characteristics. After controlling for household demographics, TOD households still spend significantly less than non-TOD households on transportation costs. The magnitudes of the differences, however, are much smaller. Compared with non-TOD households with similar demographics, TOD households save $\$ 1,232$ per year on transportation costs, accounting for $18 \%$ of their annual transportation expenditures. When controlling for both household demographics and neighborhood environment

and location, TOD households save $\$ 429$ per year on transportation costs, accounting for about $6 \%$ of their annual transportation expenditures.

In general, this study suggests that TOD can help Californian residents save money on transportation costs. The transportation cost saving has different implications for homeowners and 
renters living in TODs. Homeowners enjoy the double benefits of TOD: increased property values and savings in transportation costs. The financial benefits of TOD for renters, however, are less clear. They save money on transportation costs, but may need to pay a rent premium to live in TODs. The overall financial impact of TOD on renters thus depends on whether the transportation cost savings can outstrip the rent premium. Future studies can estimate the rent premiums in TODs and compare the findings with the results of this study.

This study also shows that the transportation cost savings are much larger when we treat TOD as an integration of rail transit and a supportive neighborhood environment. The savings are about three times larger when we consider TOD as an integration of rail transit with a supportive neighborhood environment rather than access to rail transit service only. This finding has at least two implications. The first is that when rail transit is built, it should be planned with supportive neighborhood environment, such as one with higher land use density and mixed land use. The second is that for many communities who cannot afford to build rail transit, they can focus on the transformation of their neighborhoods into less car-oriented ones. Such a transformation could have a larger impact on transportation cost savings than rail transit. Specifically, both this research and the previous studies that were discussed in the literature review section of this report show three potential areas that can facilitate a community to transition to a less auto-dependent one. The first is compact and diverse land use that allows higher development density and a mixture of residential and non-residential land use activities. Great development density supports transit ridership and mixed land use provides more destinations within a walking/biking distance. In 2021, the state of California passed three new bills (SB 8, 9, and 10) to give Californian cities the tools to upzone single-family neighborhoods. SB 10 is particularly designed to allow transit-rich communities to zone any parcel for up to 10 housing units. These bills provide a great opportunity for TOD neighborhoods to increase housing supply to allow more Californian families to live closer to public transit. The second is street design, walkability, and bikeability. To allow local residents to feel safe to walk and ride their bicycles to access public transit and other destinations, many local streets require improvements to provide complete sidewalks, separated bike paths and lanes, and road diet to slow the car traffic. The third is to lower or remove parking requirements. The requirement for an abundance of parking space increases land and construction costs, encourages vehicle ownership, and induces car use. Lowering or removing parking requirements for both residential and business structures could encourage people to shift from auto to transit modes. 


\section{Bibliography}

American Auto Association, n.d. "Your Driving Costs." https://newsroom.aaa.com/auto/yourdriving-costs/ (accessed July 12, 2020).

Austin, P.C. "An Introduction to Propensity Score Methods for Reducing the Effects of Confounding in Observational Studies." Multivariate Behavioral Research 46 (2011):399-424.

Bureau of Labor Statistics. “Consumer Expenditures in 2018." U.S. Department of Labor, 2018. https://www.bls.gov/opub/reports/consumer-expenditures/2018/home.htm (accessed July 31, 2020).

Bartholomew, K., and R. Ewing. "Hedonic Price Effects of Pedestrian- and Transit-Oriented Development." Journal of Planning Literature 26, no. 1 (2011): 18-34.

Bento, A.M., M.L. Cropper, A. M. Mobarak, and K. Vinha. "The Effects of Urban Spatial Structure on Travel Demand in the United States." The Review of Economics and Statistics 87, no. 3 (2005): 466-478.

Buhayar, N., and C. Cannon. "How California Became America's Housing Market Nightmare." Bloomberg, 2019. https://www.bloomberg.com/graphics/2019-california-housing-crisis/ (accessed August 10, 2020).

Calthorpe, P. The Next American Metropolis: Ecology, Community, and the American Dream. New York, NY: Princeton Architectural Press, 1993.

Cao, J., and X. Cao. "The Impacts of LRT, Neighborhood Characteristics, and Self-Selection on Auto Ownership: Evidence from Minneapolis-St. Paul.” Urban Studies 51, no. 10 (2014): 2068-2087.

Cervero, R., and G.B. Arrington. "Vehicle Trip Reduction Impacts of Transit-Oriented Housing." Journal of Public Transportation 11, no. 3 (2008): 1-17.

Cervero, R., and R. Ewing. "Travel and the Built Environment: A Meta-Analysis." Journal of the American Planning Association 76, no. 3 (2010): 265-294.

Chatman, D.G. "Does TOD need the T?" Journal of the American Planning Association 79, no. 1 (2013): 17-31.

Chatman, D.G., R. Xu, J. Park, and A. Spevack. "Does Transit-Oriented Gentrification Increase Driving?” Journal of Planning Education and Research 39, no. 4 (2019): 482-495.

Dawkins, C., and R. Moeckel. "Transit-Induced Gentrification: Who Will Stay, and Who Will Go?” Journal Housing Policy Debate 26, no. 4-5 (2016): 801-818. 
Deka, D. "Transit Availability and Automobile Ownership: Some Policy Implications." Journal of Planning Education and Research 21 (2002): 285-300.

Dill, J. "Transit Use and Proximity to Rail Results from Large Employment Sites in the San Francisco, California, Bay Area." Transportation Research Record: Journal of the Transportation Research Board 1835 (2003): 19-24.

Dill, J. "Transit Use at Transit-Oriented Developments in Portland, Oregon, Area." Transportation Research Record: Journal of the Transportation Research Board 2063 (2008): 159 167.

Dougherty, C. "California, Mired in a Housing Crisis, Rejects an Effort to Ease It." New York Times, January 30, 2020. https://www.nytimes.com/2020/01/30/business/economy/sb50california-housing.html (accessed January 30, 2020).

Dong, H. "If You Build Rail Transit in Suburbs, Will Development Come?" Journal of the American Planning Association 82, no. 4 (2016): 316-326.

Dong, H. "Rail-Transit-Induced Gentrification and the Affordability Paradox of TOD." Journal of Transport Geography 63 (2017): 1-10.

Duncan, M. "Would the Replacement of Park-and-Ride Facilities with Transit-Oriented Development Reduce Vehicle Kilometers Traveled in an Auto-Oriented US Region?" Transport Policy 81 (2019): 293-301.

Ewing, R., S. Hamidi, F. Gallivan, A.C. Nelson, and J.B. Grace. "Combined Effects of Compact Development, Transportation Investments, and Road User Pricing on Vehicle Miles Traveled in Urbanized Areas." Transportation Research Record: Journal of the Transportation Research Board 2397 (2013): 117-124.

Federal Transit Administration, n.d. "The National Transit Database." https://www.transit.dot.gov/ntd (accessed August 7, 2020).

Ganning, J.P. "It's Good but is it Right? An Under-the-Hood View of the Location Affordability Index." Housing Policy Debate 27, no. 6 (2017): 807-824.

Glaeser, E.L., M.E. Kahn, and J. Rappaport. "Why Do the Poor Live in Cities? The Role of Public Transportation.” Journal of Urban Economics 63, no. 1 (2018): 1-24.

Haas, P.M., G.L. Newmark, and T.R. Morrison. "Untangling Housing Cost and Transportation Interactions: The Location Affordability Index Model—Version 2 (LAIM2).” Housing Policy Debate 26, no. 4-5 (2016): 568-582.

Hamidi, S., R. Ewing, and J. Renne. "How Affordable is HUD Affordable Housing?" Housing Policy Debate 26, no. 3 (2016): 437-455. 
Holtzclaw, J., R. Clear, H. Dittmar, D. Goldstein, and P. Haas. "Location Efficiency: Neighborhood and Socio-Economic Characteristics Determine Auto Ownership and UseStudies in Chicago, Los Angeles and San Francisco." Transportation Planning and Technology 25, no. 1 (2002): 1-27.

Ho, D.E., K. Imai, G. King, and E.A. Stuart. "MatchIt: Nonparametric Preprocessing for Parametric Causal Inference.” Journal of Statistical Software 42, no. 8 (2011): 1-28.

Ibraeva, I., G. Correia, C. Silva, and A.P. Antunes. "Transit-Oriented Development: A Review of Research Achievements and Challenges." Transportation Research Part A: Policy and Practice 132 (2020): 110-130.

Kahn, M.E. "Gentrification Trends in New Transit-Oriented Communities: Evidence from 14 Cities that Expanded and Built Rail Transit Systems.” Real Estate Economics 35, no. 2 (2007): $155-182$.

Lund, H. "Reasons for Living in a Transit-Oriented Development, and Associated Transit Use." Journal of the American Planning Association 72, no. 3 (2006): 357-366.

Manson, S., J. Schroeder, D. Van Riper, T. Kugler, and S. Ruggles. "IPUMS National Historical Geographic Information System: Version 15.0 [dataset].” Minneapolis, MN: IPUMS, 2020. http://doi.org/10.18128/D050.V15.0 (accessed May 15, 2020).

Mudigonda, S., K. Ozbay, O. Ozturk, S. Iyer, and R.B. Noland. "Quantifying Transportation Benefits of Transit-Oriented Development in New Jersey." Transportation Research Record: Journal of the Transportation Research Board 2417 (2014): 111-120.

Nasri, A., and L. Zhang. "The Analysis of Transit-Oriented Development (TOD) in Washington, D.C. and Baltimore Metropolitan Areas." Transport Policy 32 (2014): 172-179.

Park, K., R. Ewing, B.C. Scheer, and G. Tian. "The Impacts of Built Environment Characteristics of Rail Station Areas on Household Travel Behavior.” Cities 74 (2018): 277-283.

Renne, J.L. "From Transit-Adjacent Development to Transit-Oriented Development." Local Environment 14, no. 1 (2008): 1-15.

Renne, J.L., T. Tolford, S. Hamidi, and R. Ewing. "The Cost and Affordability Paradox of Transit-Oriented Development: A Comparison of Housing and Transportation Costs across Transit-Oriented Development, Hybrid and Transit-Adjacent Development Station Typologies." Housing Policy Debate 26, no. 4-5 (2016): 819-834.

Smart, M.J., and N.J. Klein. "Complicating the Story of Location Affordability." Housing Policy Debate 28, no. 3 (2018): 393-410. 
Tremoulet, A., R.J. Dann, and A. Adkins. "Moving to Location Affordability? Housing Choice Vouchers and Residential Relocation in the Portland, Oregon, Region." Housing Policy Debate 26, no. 4-5 (2016): 692-713.

U.S. Department of Energy and the U.S. Environmental Protection Agency, n.d. "Find and Compare Cars." https://www.fueleconomy.gov/feg/findacar.shtml (accessed July 5, 2020).

U.S. Department of Housing \& Urban Development, n.d. "Location Affordability Index." https://www.hudexchange.info/programs/location-affordability-index/ $\quad$ (accessed July 25, 2020).

United States Census Bureau, n.d. "Longitudinal Employer-Household Dynamics." https://lehd.ces.census.gov/data/ (accessed May 18, 2020).

Van Acker, V., and F. Witlox. "Car Ownership as a Mediating variable in Car Travel Behaviour Research using a Structural Equation Modelling Approach to Identify its Dual Relationship." Journal of Transport Geography 18 (2010): 65-74.

Zhou, X., and E.J. Zolnik. "Transit-Oriented Development and Household Transportation Costs Household-Level Analysis." Transportation Research Record: Journal of the Transportation Research Board 2357 (2013): 86-94.

Zuk, M., A.H. Bierbaum, K. Chapple, K. Gorska, and A. Loukaitou-Sideris. "Gentrification, Displacement and the Role of Public Investment." Journal of Planning Literature 33, no. 1 (2018): 31-44. 


\section{Appendix}

Table A. Identify Control Group to Compare Vehicle Ownership

\begin{tabular}{|c|c|c|c|c|c|c|c|}
\hline & \multicolumn{3}{|c|}{ Pre-matched households } & \multicolumn{4}{|c|}{ Matched households } \\
\hline & TOD & non-TOD & $\begin{array}{c}\text { mean } \\
\text { difference }\end{array}$ & TOD & non-TOD & $\begin{array}{c}\text { mean } \\
\text { difference }\end{array}$ & $\begin{array}{c}\text { standardized } \\
\text { difference }\end{array}$ \\
\hline \multicolumn{8}{|c|}{ Matched by household characteristics } \\
\hline Household size & 2.23 & 2.66 & $-0.42 * *$ & 2.23 & 2.21 & 0.03 & 0.02 \\
\hline Number of drivers in household & 1.52 & 1.91 & $-0.39 * *$ & 1.52 & 1.52 & 0.00 & 0.00 \\
\hline Number of workers in household & 1.19 & 1.29 & $-0.10 * *$ & 1.19 & 1.19 & 0.00 & 0.00 \\
\hline Household income $(<\$ 25 \mathrm{~K})$ & 0.20 & 0.13 & $0.07 * *$ & 0.20 & 0.19 & 0.01 & 0.03 \\
\hline Household income ( $\$ 25 \mathrm{k}-\$ 50 \mathrm{~K})$ & 0.19 & 0.18 & 0.01 & 0.19 & 0.19 & 0.00 & 0.00 \\
\hline Household income ( $\$ 75 \mathrm{k}-\$ 100 \mathrm{~K})$ & 0.13 & 0.15 & $-0.02 * *$ & 0.13 & 0.13 & 0.00 & 0.00 \\
\hline Household income $(\$ 100 \mathrm{k}-\$ 150 \mathrm{~K})$ & 0.15 & 0.19 & $-0.04 * *$ & 0.15 & 0.16 & -0.01 & -0.02 \\
\hline Household income $(>\$ 150 \mathrm{~K})$ & 0.15 & 0.17 & $-0.02 * *$ & 0.15 & 0.15 & 0.00 & 0.00 \\
\hline College degree $($ yes $=1)$ & 0.63 & 0.64 & 0.00 & 0.63 & 0.64 & 0.00 & -0.01 \\
\hline Homeownership $($ yes $=1)$ & 0.51 & 0.78 & $-0.27 * *$ & 0.51 & 0.52 & -0.01 & -0.01 \\
\hline Living in $\mathrm{SFH}$ (yes=1) & 0.36 & 0.74 & $-0.37 * *$ & 0.36 & 0.38 & -0.01 & -0.02 \\
\hline San Francisco Bay Area (yes $=1$ ) & 0.60 & 0.30 & $0.30 * *$ & 0.60 & 0.59 & 0.00 & 0.00 \\
\hline Greater Los Angeles Region (yes $=1$ ) & 0.32 & 0.57 & $-0.24 * *$ & 0.32 & 0.33 & 0.00 & 0.00 \\
\hline Sacramento metropolitan area (yes $=1$ ) & 0.02 & 0.08 & $-0.05 * *$ & 0.02 & 0.03 & 0.00 & -0.02 \\
\hline San Diego metropolitan area (yes $=1$ ) & 0.06 & 0.06 & -0.01 & 0.06 & 0.05 & 0.00 & 0.02 \\
\hline $\mathrm{N}$ (number of observations) & 1946 & 22465 & -- & 1946 & 1946 & -- & -- \\
\hline \multicolumn{8}{|c|}{ Matched by household, neighborhood, and location } \\
\hline Household size & 2.23 & 2.66 & $-0.42 * *$ & 2.34 & 2.40 & -0.06 & -0.03 \\
\hline Number of drivers in household & 1.52 & 1.91 & $-0.39 * *$ & 1.58 & 1.60 & -0.01 & -0.02 \\
\hline Number of workers in household & 1.19 & 1.29 & $-0.10 * *$ & 1.21 & 1.23 & -0.03 & -0.04 \\
\hline Household income $(<\$ 25 \mathrm{~K})$ & 0.20 & 0.13 & $0.07 * *$ & 0.20 & 0.20 & -0.01 & -0.02 \\
\hline Household income (\$25k-\$50K) & 0.19 & 0.18 & 0.01 & 0.21 & 0.20 & 0.00 & 0.01 \\
\hline Household income ( $\$ 75 \mathrm{k}-\$ 100 \mathrm{~K})$ & 0.13 & 0.15 & $-0.02 * *$ & 0.13 & 0.15 & -0.01 & -0.04 \\
\hline Household income ( $\$ 100 \mathrm{k}-\$ 150 \mathrm{~K})$ & 0.15 & 0.19 & $-0.04 * *$ & 0.15 & 0.15 & -0.01 & -0.02 \\
\hline Household income $(>\$ 150 \mathrm{~K})$ & 0.15 & 0.17 & $-0.02 * *$ & 0.15 & 0.14 & 0.01 & 0.02 \\
\hline College degree $($ yes $=1)$ & 0.63 & 0.64 & 0.00 & 0.61 & 0.60 & 0.02 & 0.04 \\
\hline Homeownership (yes=1) & 0.51 & 0.78 & $-0.27 * *$ & 0.56 & 0.55 & 0.01 & 0.01 \\
\hline Living in SFH (yes=1) & 0.36 & 0.74 & $-0.37 * *$ & 0.43 & 0.44 & -0.01 & -0.01 \\
\hline Neighborhood density (in Log) & 3.70 & 2.28 & $1.42 * *$ & 3.47 & 3.41 & 0.06 & 0.10 \\
\hline Neighborhood mixed use & 0.23 & 0.09 & $0.14^{* *}$ & 0.16 & 0.16 & 0.00 & 0.01 \\
\hline Neighborhood income (in log) & 4.32 & 4.44 & $-0.12 * *$ & 4.31 & 4.29 & 0.02 & 0.07 \\
\hline Distance to CBD (in Log) & 1.45 & 2.68 & $-1.23 * *$ & 1.74 & 1.81 & $-0.07 * *$ & -0.07 \\
\hline San Francisco Bay Area (yes $=1$ ) & 0.60 & 0.30 & $0.30^{* *}$ & 0.54 & 0.51 & $0.03 * *$ & 0.06 \\
\hline Greater Los Angeles Region (yes $=1$ ) & 0.32 & 0.57 & $-0.24 * *$ & 0.37 & 0.39 & -0.02 & -0.03 \\
\hline Sacramento metropolitan area (yes $=1$ ) & 0.02 & 0.08 & $-0.05 * *$ & 0.03 & 0.03 & 0.00 & 0.00 \\
\hline San Diego metropolitan area (yes $=1)$ & 0.06 & 0.06 & -0.01 & 0.06 & 0.08 & $-0.01 * *$ & -0.06 \\
\hline $\mathrm{N}$ (number of observations) & 1946 & 22465 & -- & 1626 & 1626 & -- & -- \\
\hline
\end{tabular}


Table B. Identify Control Group to Compare Vehicle Fuel Efficiency

\begin{tabular}{|c|c|c|c|c|c|c|c|}
\hline & \multicolumn{3}{|c|}{ Pre-matched households } & \multicolumn{4}{|c|}{ Matched households } \\
\hline & TOD & non-TOD & $\begin{array}{c}\text { mean } \\
\text { difference }\end{array}$ & TOD & non-TOD & $\begin{array}{c}\text { mean } \\
\text { difference }\end{array}$ & $\begin{array}{c}\text { standardized } \\
\text { difference }\end{array}$ \\
\hline \multicolumn{8}{|c|}{ Matched by household characteristics } \\
\hline Household size & 2.34 & 2.64 & $-0.30^{* *}$ & 2.34 & 2.38 & -0.04 & -0.02 \\
\hline Number of drivers in household & 1.69 & 1.93 & $-0.24 * *$ & 1.69 & 1.70 & -0.01 & -0.02 \\
\hline Number of workers in household & 1.28 & 1.30 & -0.02 & 1.28 & 1.29 & 0.00 & -0.01 \\
\hline Household income $(<\$ 25 \mathrm{~K})$ & 0.12 & 0.10 & $0.02 * *$ & 0.12 & 0.13 & -0.01 & -0.04 \\
\hline Household income ( $\$ 25 \mathrm{k}-\$ 50 \mathrm{~K})$ & 0.19 & 0.18 & 0.01 & 0.19 & 0.21 & -0.02 & -0.05 \\
\hline Household income ( $\$ 75 \mathrm{k}-\$ 100 \mathrm{~K})$ & 0.15 & 0.16 & -0.01 & 0.15 & 0.14 & 0.01 & 0.03 \\
\hline Household income ( $\$ 100 \mathrm{k}-\$ 150 \mathrm{~K})$ & 0.16 & 0.20 & -0.04 & 0.16 & 0.15 & 0.01 & 0.03 \\
\hline Household income ( $>\$ 150 \mathrm{~K})$ & 0.18 & 0.18 & 0.00 & 0.18 & 0.18 & 0.00 & -0.01 \\
\hline College degree $($ yes $=1)$ & 0.68 & 0.67 & 0.01 & 0.68 & 0.65 & 0.02 & 0.05 \\
\hline Homeownership (yes $=1$ ) & 0.59 & 0.80 & $-0.21^{* *}$ & 0.59 & 0.59 & 0.00 & 0.00 \\
\hline Living in SFH (yes=1) & 0.42 & 0.75 & $-0.33 * *$ & 0.42 & 0.41 & 0.00 & 0.01 \\
\hline San Francisco Bay Area (yes $=1$ ) & 0.58 & 0.30 & $0.28 * *$ & 0.58 & 0.56 & 0.02 & 0.03 \\
\hline Greater Los Angeles Region (yes $=1$ ) & 0.34 & 0.56 & $-0.22 * *$ & 0.34 & 0.37 & $-0.03 * *$ & -0.06 \\
\hline Sacramento metropolitan area (yes $=1$ ) & 0.03 & 0.08 & $-0.05 * *$ & 0.03 & 0.02 & 0.00 & 0.03 \\
\hline San Diego metropolitan area (yes $=1$ ) & 0.06 & 0.06 & 0.00 & 0.06 & 0.05 & 0.01 & 0.03 \\
\hline $\mathrm{N}$ (number of observations) & 1261 & 17425 & -- & 1261 & 1261 & -- & -- \\
\hline \multicolumn{8}{|c|}{ Matched by household, neighborhood, and location } \\
\hline Household size & 2.34 & 2.64 & $-0.30^{* *}$ & 2.40 & 2.43 & -0.03 & -0.02 \\
\hline Number of drivers in household & 1.69 & 1.93 & $-0.24 * *$ & 1.71 & 1.72 & -0.01 & -0.02 \\
\hline Number of workers in household & 1.28 & 1.30 & -0.02 & 1.28 & 1.28 & 0.00 & 0.00 \\
\hline Household income $(<\$ 25 \mathrm{~K})$ & 0.12 & 0.10 & $0.02 * *$ & 0.13 & 0.13 & 0.00 & -0.01 \\
\hline Household income ( $\$ 25 \mathrm{k}-\$ 50 \mathrm{~K})$ & 0.19 & 0.18 & 0.01 & 0.20 & 0.19 & 0.01 & 0.03 \\
\hline Household income (\$75k-\$100K) & 0.15 & 0.16 & -0.01 & 0.15 & 0.17 & -0.02 & -0.04 \\
\hline Household income $(\$ 100 \mathrm{k}-\$ 150 \mathrm{~K})$ & 0.16 & 0.20 & -0.04 & 0.16 & 0.15 & 0.00 & 0.01 \\
\hline Household income $(>\$ 150 \mathrm{~K})$ & 0.18 & 0.18 & 0.00 & 0.16 & 0.16 & 0.00 & 0.00 \\
\hline College degree $($ yes $=1)$ & 0.68 & 0.67 & 0.01 & 0.66 & 0.64 & 0.02 & 0.04 \\
\hline Homeownership (yes $=1$ ) & 0.59 & 0.80 & $-0.21 * *$ & 0.60 & 0.61 & -0.01 & -0.01 \\
\hline Living in SFH (yes=1) & 0.42 & 0.75 & $-0.33 * *$ & 0.46 & 0.47 & -0.01 & -0.03 \\
\hline Neighborhood density (in Log) & 3.56 & 2.24 & $1.31 * *$ & 3.41 & 3.34 & 0.07 & 0.11 \\
\hline Neighborhood mixed use & 0.23 & 0.09 & $0.14 * *$ & 0.17 & 0.15 & 0.02 & 0.07 \\
\hline Neighborhood income (in log) & 4.38 & 4.46 & $-0.08^{* *}$ & 4.36 & 4.33 & 0.02 & 0.08 \\
\hline Distance to CBD (in Log) & 1.61 & 2.71 & $-1.10^{* *}$ & 1.80 & 1.86 & $-0.06^{*}$ & -0.07 \\
\hline San Francisco Bay Area (yes $=1$ ) & 0.58 & 0.30 & $0.28^{* *}$ & 0.55 & 0.54 & 0.01 & 0.02 \\
\hline Greater Los Angeles Region (yes $=1$ ) & 0.34 & 0.56 & $-0.22 * *$ & 0.36 & 0.37 & -0.01 & -0.02 \\
\hline Sacramento metropolitan area $($ yes $=1)$ & 0.03 & 0.08 & $0.05^{* *}$ & 0.03 & 0.02 & 0.01 & 0.03 \\
\hline San Diego metropolitan area (yes $=1)$ & 0.06 & 0.06 & 0.00 & 0.06 & 0.07 & -0.01 & -0.04 \\
\hline $\mathrm{N}$ (number of observations) & 1261 & 17425 & -- & 1129 & 1129 & -- & -- \\
\hline
\end{tabular}

**significant at the $1 \%$ level; *significant at the $5 \%$ level 


\section{Table C. Identify Control Group to Compare VMT}

\begin{tabular}{|c|c|c|c|c|c|c|c|}
\hline & \multicolumn{3}{|c|}{ Pre-matched households } & \multicolumn{4}{|c|}{ Matched households } \\
\hline & TOD & non-TOD & $\begin{array}{c}\text { mean } \\
\text { difference }\end{array}$ & TOD & non-TOD & $\begin{array}{c}\text { mean } \\
\text { difference }\end{array}$ & $\begin{array}{l}\text { standardized } \\
\text { difference }\end{array}$ \\
\hline \multicolumn{8}{|c|}{ Matched by household characteristics } \\
\hline Household size & 2.20 & 2.61 & $-0.41 * *$ & 2.20 & 2.21 & -0.01 & -0.01 \\
\hline Number of drivers in household & 1.49 & 1.88 & $-0.39 * *$ & 1.49 & 1.48 & 0.01 & 0.01 \\
\hline Number of workers in household & 1.17 & 1.27 & $-0.09^{* *}$ & 1.17 & 1.16 & 0.01 & 0.02 \\
\hline Household income $(<\$ 25 \mathrm{~K})$ & 0.21 & 0.14 & $0.07 * *$ & 0.21 & 0.21 & 0.00 & -0.01 \\
\hline Household income ( $\$ 25 \mathrm{k}-\$ 50 \mathrm{~K})$ & 0.19 & 0.18 & 0.01 & 0.19 & 0.21 & -0.01 & -0.04 \\
\hline Household income ( $\$ 75 \mathrm{k}-\$ 100 \mathrm{~K})$ & 0.13 & 0.15 & $-0.02 * *$ & 0.13 & 0.13 & 0.00 & 0.00 \\
\hline Household income $(\$ 100 \mathrm{k}-\$ 150 \mathrm{~K})$ & 0.15 & 0.19 & $-0.04 * *$ & 0.15 & 0.16 & 0.00 & -0.01 \\
\hline Household income (>\$150K) & 0.15 & 0.17 & $-0.02^{* *}$ & 0.15 & 0.13 & 0.02 & 0.05 \\
\hline College degree $($ yes $=1)$ & 0.63 & 0.64 & -0.01 & 0.63 & 0.61 & 0.02 & 0.04 \\
\hline Homeownership $($ yes $=1)$ & 0.51 & 0.78 & $-0.27 * *$ & 0.51 & 0.50 & 0.01 & 0.02 \\
\hline Living in $\mathrm{SFH}(\mathrm{yes}=1)$ & 0.36 & 0.73 & $-0.38^{* *}$ & 0.36 & 0.36 & -0.01 & -0.01 \\
\hline San Francisco Bay Area (yes $=1$ ) & 0.59 & 0.29 & $0.30^{* *}$ & 0.59 & 0.58 & 0.01 & 0.02 \\
\hline Greater Los Angeles Region (yes $=1$ ) & 0.33 & 0.57 & $-0.24 * *$ & 0.33 & 0.33 & 0.00 & 0.00 \\
\hline Sacramento metropolitan area (yes $=1$ ) & 0.02 & 0.08 & $-0.05^{* *}$ & 0.02 & 0.03 & 0.00 & -0.02 \\
\hline San Diego metropolitan area $(\mathrm{yes}=1)$ & 0.06 & 0.06 & 0.00 & 0.06 & 0.07 & -0.01 & -0.04 \\
\hline Assigned travel day (weekend=1) & 0.21 & 0.29 & $-0.07 * *$ & 0.21 & 0.20 & 0.01 & 0.03 \\
\hline $\mathrm{N}$ (number of observations) & 1790 & 20232 & -- & & & -- & -- \\
\hline \multicolumn{8}{|c|}{ Matched by household, neighborhood, and location } \\
\hline Household size & 2.20 & 2.61 & -0.41 & 2.32 & 2.29 & 0.03 & 0.02 \\
\hline Number of drivers in household & 1.49 & 1.88 & -0.39 & 1.55 & 1.54 & 0.01 & 0.02 \\
\hline Number of workers in household & 1.17 & 1.27 & -0.09 & 1.18 & 1.16 & 0.02 & 0.04 \\
\hline Household income $(<\$ 25 \mathrm{~K})$ & 0.21 & 0.14 & 0.07 & 0.21 & 0.20 & 0.00 & 0.01 \\
\hline Household income (\$25k-\$50K) & 0.19 & 0.18 & 0.01 & 0.20 & 0.20 & 0.01 & 0.02 \\
\hline Household income ( $\$ 75 \mathrm{k}-\$ 100 \mathrm{~K})$ & 0.13 & 0.15 & -0.02 & 0.13 & 0.13 & -0.01 & -0.02 \\
\hline Household income $(\$ 100 \mathrm{k}-\$ 150 \mathrm{~K})$ & 0.15 & 0.19 & -0.04 & 0.15 & 0.16 & -0.01 & -0.03 \\
\hline Household income $(>\$ 150 \mathrm{~K})$ & 0.15 & 0.17 & -0.02 & 0.14 & 0.14 & 0.00 & 0.01 \\
\hline College degree (yes $=1$ ) & 0.63 & 0.64 & -0.01 & 0.61 & 0.61 & 0.00 & -0.01 \\
\hline Homeownership $($ yes $=1)$ & 0.51 & 0.78 & -0.27 & 0.55 & 0.55 & 0.00 & -0.01 \\
\hline Living in SFH (yes=1) & 0.36 & 0.73 & -0.38 & 0.42 & 0.41 & 0.01 & 0.02 \\
\hline Neighborhood density (in Log) & 3.71 & 2.28 & 1.44 & 3.48 & 3.41 & $0.06^{* *}$ & 0.10 \\
\hline Neighborhood mixed use & 0.24 & 0.09 & 0.15 & 0.16 & 0.16 & 0.00 & 0.01 \\
\hline Neighborhood income (in log) & 4.32 & 4.43 & -0.12 & 4.30 & 4.29 & 0.01 & 0.02 \\
\hline Distance to CBD (in Log) & 1.44 & 2.69 & -1.24 & 1.74 & 1.83 & -0.09 & -0.09 \\
\hline San Francisco Bay Area (yes $=1$ ) & 0.59 & 0.29 & 0.30 & 0.53 & 0.52 & 0.01 & 0.02 \\
\hline Greater Los Angeles Region (yes $=1$ ) & 0.33 & 0.57 & -0.24 & 0.38 & 0.38 & -0.01 & -0.01 \\
\hline Sacramento metropolitan area (yes $=1)$ & 0.02 & 0.08 & -0.05 & 0.03 & 0.02 & 0.00 & 0.02 \\
\hline San Diego metropolitan area $($ yes $=1)$ & 0.06 & 0.06 & 0.00 & 0.06 & 0.07 & -0.01 & -0.04 \\
\hline Assigned travel day (weekend $=1$ ) & 0.21 & 0.29 & -0.07 & 0.23 & 0.24 & -0.01 & -0.02 \\
\hline $\mathrm{N}$ (number of observations) & 1790 & 20232 & -- & 1484 & 1484 & -- & -- \\
\hline
\end{tabular}

**significant at the $1 \%$ level; *significant at the $5 \%$ level 
Table D. Identify Control Group to Compare Vehicle Ownership Cost

\begin{tabular}{|c|c|c|c|c|c|c|c|}
\hline & \multicolumn{3}{|c|}{ Pre-matched households } & \multicolumn{4}{|c|}{ Matched households } \\
\hline & TOD & non-TOD & $\begin{array}{c}\text { mean } \\
\text { difference }\end{array}$ & TOD & non-TOD & $\begin{array}{c}\text { mean } \\
\text { difference }\end{array}$ & $\begin{array}{l}\text { standardized } \\
\text { difference }\end{array}$ \\
\hline \multicolumn{8}{|c|}{ Matched by household characteristics } \\
\hline Household size & 2.15 & 2.59 & $-0.45^{* *}$ & 2.15 & 2.17 & -0.02 & -0.01 \\
\hline Number of drivers in household & 1.45 & 1.85 & $-0.39 * *$ & 1.46 & 1.46 & 0.00 & -0.01 \\
\hline Number of workers in household & 1.16 & 1.26 & $-0.10 * *$ & 1.16 & 1.15 & 0.01 & 0.01 \\
\hline Household income $(<\$ 25 \mathrm{~K})$ & 0.21 & 0.14 & $0.07 * *$ & 0.21 & 0.20 & 0.01 & 0.02 \\
\hline Household income $(\$ 25 \mathrm{k}-\$ 50 \mathrm{~K})$ & 0.19 & 0.18 & 0.00 & 0.19 & 0.19 & 0.00 & 0.00 \\
\hline Household income (\$75k-\$100K) & 0.13 & 0.15 & $-0.02 * *$ & 0.13 & 0.13 & 0.00 & 0.01 \\
\hline Household income (\$100k-\$150K) & 0.15 & 0.19 & $-0.04 * *$ & 0.15 & 0.15 & 0.00 & -0.01 \\
\hline Household income ( $>\$ 150 \mathrm{~K})$ & 0.15 & 0.17 & $-0.02 * *$ & 0.15 & 0.15 & 0.00 & 0.00 \\
\hline College degree $($ yes $=1)$ & 0.63 & 0.64 & -0.01 & 0.63 & 0.62 & 0.01 & 0.02 \\
\hline Homeownership (yes=1) & 0.50 & 0.77 & $-0.27 * *$ & 0.50 & 0.50 & 0.00 & 0.00 \\
\hline Living in SFH (yes=1) & 0.34 & 0.72 & $-0.38 * *$ & 0.34 & 0.34 & 0.00 & 0.00 \\
\hline San Francisco Bay Area (yes $=1$ ) & 0.60 & 0.30 & $0.30^{* *}$ & 0.60 & 0.58 & 0.02 & 0.03 \\
\hline Greater Los Angeles Region (yes $=1$ ) & 0.32 & 0.56 & $-0.24 * *$ & 0.32 & 0.33 & -0.01 & -0.02 \\
\hline Sacramento metropolitan area (yes $=1$ ) & 0.03 & 0.08 & $-0.05 * *$ & 0.03 & 0.03 & -0.01 & -0.04 \\
\hline San Diego metropolitan area (yes=1) & 0.06 & 0.06 & 0.00 & 0.06 & 0.05 & 0.00 & 0.01 \\
\hline $\mathrm{N}$ (number of observations) & 1680 & 18569 & -- & 1676 & 1676 & -- & -- \\
\hline \multicolumn{8}{|c|}{ Matched by household, neighborhood, and location } \\
\hline Household size & 2.15 & 2.59 & $-0.45^{* *}$ & 2.26 & 2.27 & -0.01 & -0.01 \\
\hline Number of drivers in household & 1.45 & 1.85 & $-0.39 * *$ & 1.52 & 1.53 & 0.00 & 0.00 \\
\hline Number of workers in household & 1.16 & 1.26 & $-0.10 * *$ & 1.18 & 1.17 & 0.01 & 0.02 \\
\hline Household income $(<\$ 25 \mathrm{~K})$ & 0.21 & 0.14 & $0.07 * *$ & 0.20 & 0.20 & 0.00 & 0.00 \\
\hline Household income (\$25k-\$50K) & 0.19 & 0.18 & 0.00 & 0.20 & 0.20 & 0.00 & 0.00 \\
\hline Household income (\$75k-\$100K) & 0.13 & 0.15 & $-0.02 * *$ & 0.14 & 0.14 & -0.01 & -0.02 \\
\hline Household income (\$100k-\$150K) & 0.15 & 0.19 & $-0.04 * *$ & 0.15 & 0.14 & 0.01 & 0.02 \\
\hline Household income $(>\$ 150 \mathrm{~K})$ & 0.15 & 0.17 & $-0.02 * *$ & 0.14 & 0.13 & 0.01 & 0.03 \\
\hline College degree $($ yes $=1)$ & 0.63 & 0.64 & -0.01 & 0.62 & 0.60 & 0.02 & 0.04 \\
\hline Homeownership (yes=1) & 0.50 & 0.77 & $-0.27 * *$ & 0.54 & 0.54 & 0.00 & 0.00 \\
\hline Living in SFH (yes=1) & 0.34 & 0.72 & $-0.38 * *$ & 0.41 & 0.40 & 0.00 & 0.01 \\
\hline Neighborhood density (in Log) & 3.73 & 2.29 & $1.43 * *$ & 3.49 & 3.39 & $0.10^{* *}$ & 0.13 \\
\hline Neighborhood mixed use & 0.24 & 0.09 & $0.15^{* *}$ & 0.16 & 0.17 & -0.01 & -0.05 \\
\hline Neighborhood income (in log) & 4.32 & 4.43 & $-0.11 * *$ & 4.31 & 4.30 & 0.01 & 0.04 \\
\hline Distance to CBD (in Log) & 1.43 & 2.68 & $-1.25^{* *}$ & 1.75 & 1.83 & $-0.08 * *$ & -0.08 \\
\hline San Francisco Bay Area (yes=1) & 0.60 & 0.30 & $0.30^{* *}$ & 0.55 & 0.52 & 0.02 & 0.05 \\
\hline Greater Los Angeles Region (yes $=1$ ) & 0.32 & 0.56 & $-0.24 * *$ & 0.37 & 0.38 & -0.02 & -0.04 \\
\hline Sacramento metropolitan area (yes $=1$ ) & 0.03 & 0.08 & $-0.05 * *$ & 0.03 & 0.03 & -0.01 & -0.04 \\
\hline San Diego metropolitan area $($ yes $=1)$ & 0.06 & 0.06 & 0.00 & 0.06 & 0.06 & 0.00 & 0.00 \\
\hline $\mathrm{N}$ (number of observations) & 1680 & 18569 & -- & 1382 & 1382 & -- & -- \\
\hline
\end{tabular}

**significant at the $1 \%$ level; *significant at the $5 \%$ level 


\section{Table E. Identify Control Group to Compare Vehicle Operating Cost}

\begin{tabular}{|c|c|c|c|c|c|c|c|}
\hline & \multicolumn{3}{|c|}{ Pre-matched households } & \multicolumn{4}{|c|}{ Matched households } \\
\hline & TOD & non-TOD & $\begin{array}{c}\text { mean } \\
\text { difference }\end{array}$ & TOD & non-TOD & $\begin{array}{c}\text { mean } \\
\text { difference }\end{array}$ & $\begin{array}{l}\text { standardized } \\
\text { difference }\end{array}$ \\
\hline \multicolumn{8}{|c|}{ Matched by household characteristics } \\
\hline Household size & 2.22 & 2.62 & $-0.40^{* *}$ & 2.25 & 2.33 & -0.08 & -0.05 \\
\hline Number of drivers in household & 1.51 & 1.90 & $-0.39 * *$ & 1.52 & 1.57 & -0.04 & -0.06 \\
\hline Number of workers in household & 1.18 & 1.28 & $-0.10^{* *}$ & 1.17 & 1.20 & -0.03 & -0.04 \\
\hline Household income $(<\$ 25 \mathrm{~K})$ & 0.20 & 0.13 & $0.07 * *$ & 0.20 & 0.20 & 0.00 & 0.01 \\
\hline Household income ( $\$ 25 \mathrm{k}-\$ 50 \mathrm{~K})$ & 0.19 & 0.18 & 0.01 & 0.20 & 0.18 & 0.01 & 0.04 \\
\hline Household income (\$75k-\$100K) & 0.13 & 0.16 & $-0.02 * *$ & 0.13 & 0.13 & 0.00 & 0.00 \\
\hline Household income ( $\$ 100 \mathrm{k}-\$ 150 \mathrm{~K})$ & 0.15 & 0.19 & $-0.04 * *$ & 0.15 & 0.16 & -0.01 & -0.03 \\
\hline Household income (>\$150K) & 0.15 & 0.17 & $-0.02 * *$ & 0.15 & 0.14 & 0.00 & 0.01 \\
\hline College degree $(\mathrm{yes}=1)$ & 0.63 & 0.65 & -0.02 & 0.62 & 0.62 & 0.00 & 0.00 \\
\hline Homeownership $($ yes $=1)$ & 0.52 & 0.79 & $-0.27 * *$ & 0.54 & 0.52 & 0.02 & 0.03 \\
\hline Living in $\mathrm{SFH}(\mathrm{yes}=1)$ & 0.37 & 0.74 & $-0.37 * *$ & 0.38 & 0.40 & -0.02 & -0.03 \\
\hline San Francisco Bay Area (yes=1) & 0.59 & 0.30 & $0.29 * *$ & 0.58 & 0.58 & 0.00 & -0.01 \\
\hline Greater Los Angeles Region (yes $=1$ ) & 0.33 & 0.56 & $-0.24 * *$ & 0.34 & 0.33 & 0.01 & 0.01 \\
\hline Sacramento metropolitan area $($ yes $=1$ ) & 0.03 & 0.08 & $-0.05 * *$ & 0.03 & 0.04 & $-0.01 * *$ & -0.05 \\
\hline San Diego metropolitan area (yes $=1$ ) & 0.06 & 0.06 & 0.00 & 0.06 & 0.05 & 0.01 & 0.04 \\
\hline Assigned travel day (weekend=1) & 0.21 & 0.29 & $-0.07 * *$ & 0.22 & 0.22 & 0.00 & -0.01 \\
\hline $\mathrm{N}$ (number of observations) & 1640 & 19378 & -- & 1636 & 1636 & -- & -- \\
\hline \multicolumn{8}{|c|}{ Matched by household, neighborhood, and location } \\
\hline Household size & 2.22 & 2.62 & $-0.40 * *$ & 2.33 & 2.36 & -0.03 & -0.02 \\
\hline Number of drivers in household & 1.51 & 1.90 & $-0.39^{* *}$ & 1.57 & 1.58 & -0.02 & -0.02 \\
\hline Number of workers in household & 1.18 & 1.28 & $-0.10 * *$ & 1.19 & 1.21 & -0.02 & -0.04 \\
\hline Household income ( $<\$ 25 \mathrm{~K})$ & 0.20 & 0.13 & $0.07 * *$ & 0.19 & 0.19 & 0.01 & 0.01 \\
\hline Household income ( $\$ 25 \mathrm{k}-\$ 50 \mathrm{~K})$ & 0.19 & 0.18 & 0.01 & 0.21 & 0.22 & -0.02 & -0.04 \\
\hline Household income (\$75k-\$100K) & 0.13 & 0.16 & $-0.02 * *$ & 0.13 & 0.14 & -0.01 & -0.02 \\
\hline Household income ( $\$ 100 \mathrm{k}-\$ 150 \mathrm{~K})$ & 0.15 & 0.19 & $-0.04 * *$ & 0.15 & 0.14 & 0.02 & 0.05 \\
\hline Household income ( $>\$ 150 \mathrm{~K})$ & 0.15 & 0.17 & $-0.02 * *$ & 0.14 & 0.15 & 0.00 & -0.01 \\
\hline College degree $($ yes $=1)$ & 0.63 & 0.65 & -0.02 & 0.61 & 0.60 & 0.01 & 0.02 \\
\hline Homeownership (yes=1) & 0.52 & 0.79 & $-0.27 * *$ & 0.56 & 0.56 & 0.01 & 0.01 \\
\hline Living in SFH (yes=1) & 0.37 & 0.74 & $-0.37 * *$ & 0.44 & 0.44 & -0.01 & -0.01 \\
\hline Neighborhood density (in Log) & 3.69 & 2.26 & $1.42 * *$ & 3.46 & 3.34 & $0.12 * *$ & 0.16 \\
\hline Neighborhood mixed use & 4.32 & 4.44 & $-0.12 * *$ & 4.31 & 4.31 & 0.00 & 0.01 \\
\hline Neighborhood income (in log) & 0.24 & 0.09 & $0.15^{* *}$ & 0.16 & 0.17 & 0.00 & -0.01 \\
\hline Distance to CBD (in Log) & 1.46 & 2.69 & $-1.23 * *$ & 1.75 & 1.80 & -0.05 & -0.05 \\
\hline San Francisco Bay Area (yes $=1$ ) & 0.59 & 0.30 & $0.29^{* *}$ & 0.54 & 0.54 & 0.00 & -0.01 \\
\hline Greater Los Angeles Region (yes $=1$ ) & 0.33 & 0.56 & $-0.24 * *$ & 0.37 & 0.36 & 0.01 & 0.02 \\
\hline Sacramento metropolitan area $($ yes $=1$ ) & 0.03 & 0.08 & $-0.05 * *$ & 0.03 & 0.03 & $0.00 * *$ & 0.01 \\
\hline San Diego metropolitan area (yes=1) & 0.06 & 0.06 & 0.00 & 0.06 & 0.07 & -0.01 & -0.03 \\
\hline Assigned travel day (weekend $=1$ ) & 0.21 & 0.29 & $-0.07 * *$ & 0.22 & 0.23 & -0.01 & -0.02 \\
\hline $\mathrm{N}$ (number of observations) & 1640 & 19378 & -- & 1376 & 1376 & -- & -- \\
\hline
\end{tabular}

**significant at the $1 \%$ level; *significant at the $5 \%$ level 


\section{Table F. Identify Control Group to Compare Transit Cost}

\begin{tabular}{|c|c|c|c|c|c|c|c|}
\hline & \multicolumn{3}{|c|}{ Pre-matched households } & \multicolumn{4}{|c|}{ Matched households } \\
\hline & TOD & non-TOD & $\begin{array}{c}\text { mean } \\
\text { difference }\end{array}$ & TOD & non-TOD & $\begin{array}{c}\text { mean } \\
\text { difference }\end{array}$ & $\begin{array}{c}\text { standardized } \\
\text { difference }\end{array}$ \\
\hline \multicolumn{8}{|c|}{ Matched by household characteristics } \\
\hline Household size & 2.24 & 2.66 & $-0.42^{* *}$ & 2.24 & 2.24 & 0.00 & 0.00 \\
\hline Number of drivers in household & 1.52 & 1.92 & $-0.39 * *$ & 1.52 & 1.52 & 0.00 & 0.00 \\
\hline Number of workers in household & 1.20 & 1.29 & $-0.10^{* *}$ & 1.20 & 1.18 & 0.01 & 0.02 \\
\hline Household income $(<\$ 25 \mathrm{~K})$ & 0.20 & 0.13 & $0.07^{* *}$ & 0.20 & 0.20 & 0.00 & -0.01 \\
\hline Household income ( $\$ 25 \mathrm{k}-\$ 50 \mathrm{~K})$ & 0.19 & 0.18 & 0.01 & 0.19 & 0.20 & -0.01 & -0.02 \\
\hline Household income ( $\$ 75 \mathrm{k}-\$ 100 \mathrm{~K})$ & 0.13 & 0.15 & $-0.02 * *$ & 0.13 & 0.12 & 0.01 & 0.03 \\
\hline Household income ( $\$ 100 \mathrm{k}-\$ 150 \mathrm{~K})$ & 0.15 & 0.19 & $-0.04 * *$ & 0.15 & 0.15 & 0.01 & 0.02 \\
\hline Household income $(>\$ 150 \mathrm{~K})$ & 0.15 & 0.17 & $-0.02 * *$ & 0.15 & 0.14 & 0.01 & 0.02 \\
\hline College degree $($ yes $=1)$ & 0.63 & 0.64 & 0.00 & 0.63 & 0.63 & 0.00 & 0.00 \\
\hline Homeownership (yes=1) & 0.52 & 0.78 & $-0.27 * *$ & 0.52 & 0.52 & 0.00 & 0.00 \\
\hline Living in SFH (yes=1) & 0.37 & 0.74 & $-0.37 * *$ & 0.37 & 0.36 & 0.00 & 0.01 \\
\hline Metro: Bay Area & 0.59 & 0.30 & $0.30^{* *}$ & 0.59 & 0.58 & $0.02 *$ & 0.03 \\
\hline Metro: Los Angeles & 0.32 & 0.57 & $-0.24 * *$ & 0.32 & 0.34 & -0.01 & -0.02 \\
\hline Metro: Sacramentao & 0.02 & 0.08 & $0.05^{* *}$ & 0.02 & 0.03 & $-0.01 *$ & -0.04 \\
\hline Metro: San Diego & 0.06 & 0.06 & -0.01 & 0.06 & 0.06 & 0.00 & 0.00 \\
\hline $\mathrm{N}$ (number of observations) & 1934 & 22394 & -- & 1934 & 1934 & -- & -- \\
\hline \multicolumn{8}{|c|}{ Matched by household, neighborhood, and location } \\
\hline Household size & 2.24 & 2.66 & $-0.42 * *$ & 2.35 & 2.43 & -0.09 & -0.05 \\
\hline Number of drivers in household & 1.52 & 1.92 & $-0.39^{* *}$ & 1.58 & 1.59 & -0.01 & -0.02 \\
\hline Number of workers in household & 1.20 & 1.29 & $-0.10^{* *}$ & 1.21 & 1.20 & 0.01 & 0.01 \\
\hline Household income $(<\$ 25 \mathrm{~K})$ & 0.20 & 0.13 & $0.07^{* *}$ & 0.20 & 0.19 & 0.01 & 0.02 \\
\hline Household income ( $\$ 25 \mathrm{k}-\$ 50 \mathrm{~K})$ & 0.19 & 0.18 & 0.01 & 0.21 & 0.22 & -0.01 & -0.03 \\
\hline Household income ( $\$ 75 \mathrm{k}-\$ 100 \mathrm{~K})$ & 0.13 & 0.15 & $-0.02 * *$ & 0.13 & 0.13 & 0.00 & 0.00 \\
\hline Household income $(\$ 100 \mathrm{k}-\$ 150 \mathrm{~K})$ & 0.15 & 0.19 & $-0.04 * *$ & 0.15 & 0.16 & -0.01 & -0.02 \\
\hline Household income $(>\$ 150 \mathrm{~K})$ & 0.15 & 0.17 & $-0.02 * *$ & 0.14 & 0.14 & 0.00 & 0.01 \\
\hline College degree $(\mathrm{yes}=1)$ & 0.63 & 0.64 & 0.00 & 0.61 & 0.62 & -0.01 & -0.02 \\
\hline homeownership (yes=1) & 0.52 & 0.78 & $-0.27 * *$ & 0.56 & 0.56 & 0.00 & 0.00 \\
\hline Living in SFH (yes=1) & 0.37 & 0.74 & $-0.37 * *$ & 0.43 & 0.43 & 0.00 & 0.00 \\
\hline Neighborhood density (in Log) & 3.70 & 2.27 & $1.42 * *$ & 3.47 & 3.39 & $0.08^{* *}$ & 0.12 \\
\hline Neighborhood mixed use & 0.23 & 0.09 & $0.15^{* *}$ & 0.16 & 0.16 & 0.00 & 0.02 \\
\hline Neighborhood income (in log) & 4.32 & 4.44 & $-0.12^{* *}$ & 4.31 & 4.28 & 0.03 & 0.08 \\
\hline Distance to CBD (miles in Log) & 1.45 & 2.68 & $-1.23 * *$ & 1.74 & 1.83 & $-0.09 * *$ & -0.10 \\
\hline Metro: Bay Area & 0.59 & 0.30 & $0.30^{* *}$ & 0.55 & 0.52 & 0.02 & 0.05 \\
\hline Metro: Los Angeles & 0.32 & 0.57 & $-0.24 * *$ & 0.37 & 0.37 & -0.01 & -0.01 \\
\hline Metro: Sacramentao & 0.02 & 0.08 & $0.05^{* *}$ & 0.02 & 0.03 & 0.00 & -0.03 \\
\hline Metro: San Diego & 0.06 & 0.06 & -0.01 & 0.06 & 0.07 & $-0.01 * *$ & -0.05 \\
\hline $\mathrm{N}$ (number of observations) & 1934 & 22394 & -- & 1619 & 1619 & -- & -- \\
\hline
\end{tabular}

**significant at the $1 \%$ level; *significant at the $5 \%$ level 


\section{About the Author}

\section{Hongwei Dong}

Dr. Hongwei Dong is a professor in the Department of Geography and City and Regional Planning at California State University, Fresno. His research focuses on housing and real estate, transportation and land use, and smart and healthy cities. 


\author{
Founder, Honorable \\ Norman Mineta* \\ Secretary (ret.), \\ US Department of Transportation \\ Chair, \\ Will Kempton \\ Retired Transportation Executive \\ Vice Chair, \\ Jeff Morales \\ Managing Principal \\ InfraStrategies, LLC \\ Executive Director, \\ Karen Philbrick, $\mathrm{PhD}^{*}$ \\ Mineta Transportation Institute \\ San José State University \\ Winsome Bowen \\ Vice President, Project Development \\ Strategy \\ WSP \\ David Castagnetti \\ Co-Founder \\ Mehlman Castagnetti Rosen \& \\ Thomas \\ Maria Cino \\ Vice President, America \& U.S. \\ Government Relations \\ Hewlett-Packard Enterprise \\ Grace Crunican** \\ Owner \\ Crunican LLC \\ Donna DeMartino \\ Managing Director \\ Los Angeles-San Diego-San Luis \\ Obispo Rail Corridor Agency
}

\section{Directors}

Karen Philbrick, PhD

Executive Director

Hilary Nixon, PhD

Deputy Executive Director

Asha Weinstein Agrawal, PhD

Education Director

National Transportation Finance Center Director

Brian Michael Jenkins National Transportation Security Center Director
John Flaherty

Senior Fellow

Silicon Valley American Leadership

Forum

William Flynn *

President \& CEO

Amtrak

Rose Guilbault

Board Member

Peninsula Corridor Joint Power

Board

Ian Jefferies*

President \& CEO

Association of American Railroads

Diane Woodend Jones

Principal \& Chair of Board

Lea \& Elliott, Inc.

David S. Kim*

Secretary

California State Transportation

Agency (CALSTA)

Therese McMillan

Executive Director

Metropolitan Transportation

Commission (MTC)

Abbas Mohaddes

President \& COO

Econolite Group Inc.

Stephen Morrissey

Vice President - Regulatory and

Policy

United Airlines
Dan Moshavi, $\mathrm{PhD}^{*}$

Dean

Lucas College and GraduateSchool

of Business, San José State

University

Toks Omishakin*

Director

California Department of

Transportation (Caltrans)

Takayoshi Oshima

Chairman \& CEO

Allied Telesis, Inc.

Greg Regan

President

Transportation Trades Department, AFL-CIO

Paul Skoutelas*

President \& CEO

American Public Transportation

Association (APTA)

Kimberly Slaughter

CEO

Systra USA

Beverley Swaim-Staley

President

Union Station Redevelopment

Corporation

Jim Tymon*

Executive Director

American Association of State

Highway and Transportation

Officials (AASHTO)

$*$ Ex-Officio

** = Past Chair, Board of Trustees 